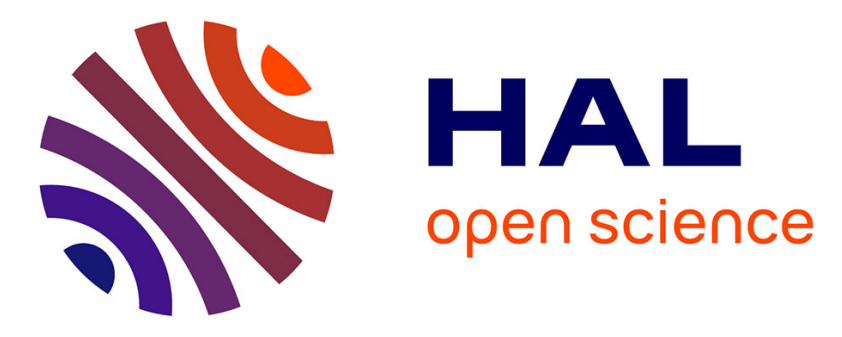

\title{
Bimetallic Ni-Zn/TiO2 catalysts for selective hydrogenation of alkyne and alkadiene impurities from
} alkenes stream

Zhao Wang, Guillaume Wang, Catherine Louis, Laurent Delannoy

\section{- To cite this version:}

Zhao Wang, Guillaume Wang, Catherine Louis, Laurent Delannoy. Bimetallic Ni-Zn/TiO2 catalysts for selective hydrogenation of alkyne and alkadiene impurities from alkenes stream. Research on Chemical Intermediates, 2021, 47 (1), pp.91-116. 10.1007/s11164-020-04327-0 . hal-03146611

\section{HAL Id: hal-03146611 https: / hal.sorbonne-universite.fr/hal-03146611}

Submitted on 19 Feb 2021

HAL is a multi-disciplinary open access archive for the deposit and dissemination of scientific research documents, whether they are published or not. The documents may come from teaching and research institutions in France or abroad, or from public or private research centers.
L'archive ouverte pluridisciplinaire HAL, est destinée au dépôt et à la diffusion de documents scientifiques de niveau recherche, publiés ou non, émanant des établissements d'enseignement et de recherche français ou étrangers, des laboratoires publics ou privés. 


\title{
Bimetallic $\mathrm{Ni}-\mathrm{Zn} / \mathrm{TiO}_{2}$ catalysts for selective hydrogenation of alkyne and alkadiene impurities from alkenes stream
}

\author{
Zhao Wang ${ }^{1,3}$, Guillaume Wang ${ }^{2}$, Catherine Louis ${ }^{1}$, Laurent Delannoy ${ }^{1 *}$
}

1- Sorbonne Université, CNRS, Laboratoire de Réactivité de Surface, LRS, F-75252 Paris, France.

2- Université Paris Diderot, Sorbonne Paris Cité, CNRS, Laboratoire Matériaux et Phénomènes Quantiques, UMR 7162, 75013, Paris, France.

3- Present address: State Key Laboratory Advance Technology for Materials Synthesis and Processing, School of Materials Science and Engineering, Wuhan University of Technology, 122, Luoshi Road, Wuhan, 430070, China.

Running title: Bimetallic $\mathrm{Ni}-\mathrm{Zn} / \mathrm{TiO}_{2}$ catalysts for selective hydrogenation of alkyne and alkadiene impurities from alkenes stream.

* To whom correspondence should be addressed:

E-mail: laurent.delannoy@sorbonne-universite.fr

Keywords: Deposition-precipitation, Ni-Zn/ $/ \mathrm{TiO}_{2}$, Nanoalloy, Bimetallic catalysts, Selective hydrogenation. 


\section{ABSTRACT}

This study investigates the alternative of replacing noble metals by base metals as catalysts for selective hydrogenation of polyunsaturated hydrocarbons. Nickel catalysts are active for this type of reaction, but poorly selective. However, former calculations anticipated that $\mathrm{Ni}-\mathrm{Zn}$ alloys could have higher selectivity to alkenes than monometallic Ni depending on the $\mathrm{Ni} / \mathrm{Zn}$ atomic ratio in the alloy. In this contribution, $\mathrm{Ni}-\mathrm{Zn}$ alloy nanoparticles supported on $\mathrm{TiO}_{2}$ are synthesized as catalysts for selective hydrogenation of acetylene and butadiene. The designed catalysts with $0.5 \mathrm{wt} \% \mathrm{Ni}$ loading and various $\mathrm{Ni} / \mathrm{Zn}$ nominal ratios are prepared by deposition-precipitation with urea (DPU). STEM-HAADF imaging coupled with EDS analysis reveals that $\mathrm{Ni}-\mathrm{Zn}$ bimetallic particles are formed after reduction treatment at $450{ }^{\circ} \mathrm{C}$. Alloying Ni with Zn leads to a slight increase of the average particle size and a broadening of the size distribution compared to monometallic Ni. However, the average $\mathrm{Ni} / \mathrm{Zn}$ atomic ratio measured by EDS in the bimetallic particles is always higher than the nominal one, which could be due to $\mathrm{Zn}$ evaporation under the beam. The results of acetylene hydrogenation show that although the catalytic activity is slightly reduced after alloying $\mathrm{Ni}$ with $\mathrm{Zn}$, the selectivity to ethylene is enhanced from $50 \%$ up to $85 \%$, at the expense of the formation of oligomers (coupling products). However, the bimetallic Ni-Zn catalysts suffer from progressive deactivation in this reaction. During butadiene hydrogenation performed in the presence of an excess of propene, the bimetallic $\mathrm{Ni}-\mathrm{Zn} / \mathrm{TiO}_{2}$ catalysts are significantly more stable, with a high and constant selectivity to butenes ( $>95 \%$ ), compared with $\mathrm{Ni} / \mathrm{TiO}_{2}$, which deactivates rapidly in the first hours. Some hypotheses concerning the observed differences in catalytic stability are discussed. 


\section{INTRODUCTION}

Light alkenes resulting from steam cracking of petroleum alkanes are required to have high purity for industrial polymer synthesis as the alkynes and alkadienes impurities contained in these alkenes streams can poison the catalysts used for the polymerization reactions [1]. For instance, the acetylene concentration in ethylene stream must be controlled to be less than 5 ppm for the synthesis of polymer grade ethylene [2], and methyl acetylene-propadiene (MAPD) is only tolerable at concentration lower than $1 \mathrm{ppm}$ in the polymer grade propylene [3]. Considering the high amount of alkynes and alkadienes impurities in raw light alkenes steams, for instance 2.0 to $8.0 \%$ of propyne and propadiene in propene [4] and 0.3 to $6.0 \%$ of residual butadiene in butenes $[5,6]$, these impurities must be eliminated before the polymerization process. Currently, catalytic semi-hydrogenation is the main way to reduce the impurities by transforming them to light alkenes without over-hydrogenation to alkanes or formation of oligomers.

Palladium-based catalysts, e.g., $\mathrm{Pd} / \mathrm{Al}_{2} \mathrm{O}_{3}$ with low metal loading (ca. 0.3 wt \%), prepared by impregnation and commercialized by Sud-Chemie $[7,8]$ have been recognized as one of the best catalysts for industrial semi-hydrogenation reactions. Even though monometallic palladium catalysts have high activity, their selectivity to alkenes decreases dramatically at high alkyne or alkadiene conversion. For instance, the selectivity to ethylene decreases from 90 to $10 \%$ when acetylene conversion increases from 80 to $100 \%$ for selective acetylene hydrogenation in excess of ethylene on $3 \mathrm{wt} \% \mathrm{Pd} /$ boehmite catalyst [9]. Thus, palladiumbased catalysts are usually modified either by inclusion of carbon, sulfur, co-feeding with $\mathrm{CO}$ [10-12], or alloying with a second metal, e.g., Pd-Pt or Pd-Ag [9, 13-16]. It was found that the addition of a second metal could prevent the diffusion of hydrogen into the metal subsurface [17] and thus hinder over-hydrogenation [18]. In addition to the selectivity, the cost of the catalysts is also of great importance for practical applications. Typically, this cost can be 
reduced either by lowering the noble metal loading in the catalysts or by developing new nonnoble metals catalysts. In the last decade, several approaches have been explored in the literature [19]. One approach is to nanostructure less conventional metals than $\mathrm{Pd}$, such as $\mathrm{Au}$ and $\mathrm{Ag}$, to create large amount of surface defects, which can promote $\mathrm{H}_{2}$ activation. The other one is to alloy palladium with other metals (e.g., $\mathrm{Ag}, \mathrm{Cu}, \mathrm{Zn}, \mathrm{Ga}$ ) to provide controlled ensembles of atoms and/or to modify the electronic properties of the active sites for adsorption of reactants and products $[20,21]$. In the hydrogenation of butadiene, $\mathrm{Al}_{2} \mathrm{O}_{3}$-supported $\mathrm{Pd}-\mathrm{Ni}$ alloy catalysts show a higher catalytic activity and selectivity to 1-butene than palladium catalysts as alloying with $\mathrm{Ni}$ decreases the activation barrier for hydrogenation and the 1-butene binding energy [22]. In acetylene hydrogenation, bimetallic Pd-Cu catalysts have lower activity but higher stability than palladium catalysts because the addition of copper reduces the reaction of oligomerization (green oil formation and accumulation) by decreasing multiple $\mathrm{Pd}$ sites for adsorption of acetylene [23]. Other Pd-based catalysts, such as Pd-Pt catalysts (BASF NanoSelect ${ }^{\mathrm{TM}}$ catalysts), were developed using colloidal deposition method and showed higher performance than the classical Lindlar's catalysts (Pd catalysts modified by lead or sulfur) in liquid phase selective hydrogenation reactions [24]. However, the high cost of Pd-based catalysts is still a concern and it would be very interesting and valuable to replace palladium by low cost non-noble metal elements.

Through density functional theory calculations (DFT), Studt et al [25] proposed that some non-noble bimetallic catalysts, such as $\mathrm{Cu}-\mathrm{Zn}, \mathrm{Fe}-\mathrm{Zn}$ and Ni-Zn, could be valuable alternatives to palladium ones. Our group has recently experimentally verified that supported bimetallic $\mathrm{Cu}-\mathrm{Zn}$ nanoparticles have high activity and selectivity as well as higher stability in selective hydrogenation of butadiene than monometallic $\mathrm{Cu}$ as the interaction with $\mathrm{Zn}$ decreases oligomers formation on the catalyst surface [26]. In the article mentioned above [25], experimental results showed that the addition of $\mathrm{Zn}$ to $\mathrm{Ni} / \mathrm{MgAl}_{2} \mathrm{O}_{4}$ with a $\mathrm{Ni} / \mathrm{Zn}$ ratio of $1 / 3$ 
resulted in the formation of a lower amount of ethane than monometallic Ni catalyst during selective hydrogenation of acetylene, but no evidence of $\mathrm{Ni}-\mathrm{Zn}$ alloy formation was reported, and the Ni-Zn catalysts stability was not studied. More recently, Spanjers et al [27] studied bulk intermetallic Ni-Zn compounds $\left(\mathrm{Ni}_{4} \mathrm{Zn}_{1}, \mathrm{Ni}_{1} \mathrm{Zn}_{1}\right.$ and $\mathrm{Ni}_{5} \mathrm{Zn}_{21}$ alloys) for selective acetylene hydrogenation in excess of ethylene and found that zinc inclusion into nickel could reduce the oligomerization reaction, leading to higher selectivity to ethylene. To extend the study to supported nanoparticles, they carried another work on $\mathrm{Ni} / \mathrm{ZnO}$ and $\mathrm{Ni} / \mathrm{SiO}_{2}$ catalysts [28] and found that Ni-Zn nano-alloys $\left(\alpha-\mathrm{NiZn}\left(\mathrm{Ni}_{4} \mathrm{Zn}\right)\right.$ or $\beta$-NiZn $\left(\mathrm{Ni}_{1} \mathrm{Zn}_{1}\right)$ depending on the sample reduction temperature) were formed directly in $\mathrm{Ni} / \mathrm{ZnO}$ sample after reduction at temperature higher than $300{ }^{\circ} \mathrm{C}$, without any monometallic Ni particle formation. However, they found that $\mathrm{Ni} / \mathrm{ZnO}$ catalysts displayed a lower selectivity to ethylene than $\mathrm{Ni} / \mathrm{SiO}_{2}$ as a result of oligomerization reactions occurring on the $\mathrm{ZnO}$ support, and they concluded that the $\mathrm{ZnO}$ support had a negative effect on ethylene selectivity. In addition, Ni-based catalysts have also been explored by adding other elements, e.g., $\mathrm{Cu}$ [29], Fe [30], $\mathrm{B}$ and $\mathrm{P}$ [31-33] for selective hydrogenation reactions. Liu et al [34] also found that unsupported intermetallics $\mathrm{Ni}_{\mathrm{x}} \mathrm{M}_{\mathrm{y}}$ $(\mathrm{M}=\mathrm{Ga}, \mathrm{Sn})$ have excellent selectivity toward alkenes and good stability during long-term acetylene hydrogenation. A promotional effect of Indium in $\mathrm{Ni}_{\mathrm{x}} \mathrm{In} / \mathrm{SiO}_{2}$ catalysts for some specific $\mathrm{Ni} /$ In ratios on acetylene conversion, ethylene selectivity and catalyst stability was also observed [35].

Since the Ni-Zn catalysts could present interesting catalytic performances [25], it was valuable and interesting to explore the preparation of bimetallic Ni-Zn catalysts supported on another support than $\mathrm{ZnO}$. Our choice went to $\mathrm{TiO}_{2}$, which has stable surface at low reduction temperature [36] and no catalytic activity for hydrogenation reaction. In this work, $\mathrm{TiO}_{2}$ supported $\mathrm{Ni}-\mathrm{Zn}$ catalysts are prepared by deposition-precipitation with urea (DPU). They are deeply characterized and the catalytic performances including activity, selectivity, and stability 
are evaluated in the hydrogenation of pure acetylene in the one hand and the selective hydrogenation of butadiene in the presence of an excess of propene in the other hand.

\section{EXPERIMENTAL SECTION}

\subsection{Catalysts preparation}

Monometallic $\mathrm{Ni} / \mathrm{TiO}_{2}$ and bimetallic $\mathrm{Ni}-\mathrm{Zn} / \mathrm{TiO}_{2}$ catalysts were prepared using the method of deposition-precipitation with urea (DPU) as described previously [37-39] to reach a nickel loading of $0.5 \mathrm{wt} \%$. Briefly, after filling a double wall reactor with $300 \mathrm{ml}$ of distilled water, $3 \mathrm{~g}$ of support $\left(\mathrm{TiO}_{2}\right.$ P25 Evonik, $80 \%$ anatase and $20 \%$ rutile, $\left.50 \mathrm{~m}^{2} \mathrm{~g}^{-1}\right)$ were added. The reactor was heated to $80{ }^{\circ} \mathrm{C}$ by a water heating system. Then, an appropriate amount of $\mathrm{Ni}\left(\mathrm{NO}_{3}\right)_{2} \cdot 6 \mathrm{H}_{2} \mathrm{O}$ and/or $\mathrm{Zn}\left(\mathrm{NO}_{3}\right)_{2} \cdot 6 \mathrm{H}_{2} \mathrm{O}$ precursors was added into the reactor to achieve the desired nominal nickel and zinc loadings $(0.5 \mathrm{wt} \% \mathrm{Ni}$ loading with $\mathrm{Ni}: \mathrm{Zn}$ atomic ratios of 1:0, 1:1, 1:3 and 1:5, the samples will be labelled Ni, NiZn1, NiZn3 and NiZn5 respectively). Meanwhile, urea was added to achieve a urea to metal molar ratio of 100 . The mixture was kept at $80{ }^{\circ} \mathrm{C}$ in the closed reactor for $20 \mathrm{~h}$ under continuous stirring. The solids were finally separated from the liquid by centrifugation and subsequently washed with distilled water and centrifuged (three times). All the samples were further dried under vacuum at room temperature (RT) for $24 \mathrm{~h}$ (as-prepared sample).

Before characterization or catalytic reaction, the as-prepared samples were calcined at $400{ }^{\circ} \mathrm{C}$ for $2 \mathrm{~h}$ after sample heating with a rate of $5{ }^{\circ} \mathrm{C} \min ^{-1}$, under flowing air $\left(100 \mathrm{~mL} \mathrm{~min}{ }^{-1}\right)$, then reduced at $450{ }^{\circ} \mathrm{C}$ for $2 \mathrm{~h}$ with a heating rate of $3{ }^{\circ} \mathrm{C} \mathrm{min}^{-1}$, under flowing pure $\mathrm{H}_{2}(100$ $\left.\mathrm{mL} \min ^{-1}\right)$. 


\subsection{Instrumentation and measurements}

The metals loadings in each sample were detected by X-ray fluorescence (XRF) with a spectrometer XEPOS HE (AMETEK). The method used for the XRF analyses is based on calibration curves obtained from standards for each element.

The reduction of the calcined samples was followed by temperature programmed reduction (TPR), which was performed on a Micromeritics Autochem II Automated Catalyst Characterization System under $5 \% \mathrm{H}_{2} / \mathrm{Ar}$ gas mixture $\left(25 \mathrm{~mL} \mathrm{~min}^{-1}\right) .100 \mathrm{mg}$ of catalyst was filled into the reactor and the hydrogen consumption was recorded during temperature increase from RT to $550{ }^{\circ} \mathrm{C}$ with a heating rate of $7.5^{\circ} \mathrm{C} \mathrm{min}^{-1} . \mathrm{H}_{2}$ consumption for $\mathrm{Ni}^{2+}$ ions reduction was calibrated using $100 \mathrm{mg}$ of pure $\mathrm{NiO}$ as a reference.

XRD analysis was performed on the reduced samples with a diffractometer (D8 Bruker Company) using the $\mathrm{Cu} \mathrm{K} \alpha$ radiation (1.5418 $\AA$; $40 \mathrm{kV}$ and $30 \mathrm{~mA}$ ) with a Ni filter under air. The crystallite sizes were calculated using Scherrer's equation [40], and correction for instrumental broadening was applied. In the diffractograms, the (200) peak of anatase $\mathrm{TiO}_{2}$ at $2 \theta=48.1$ was used as a reference to determine the position of the diffraction peaks of nickelcontaining compounds as it does not interfere with any of them.

Scanning and transmission electron microscopy with high-angle annular dark-field (STEM-HAADF) and energy-dispersive X-ray spectroscopy (EDS) were used to identify the size and compositions of the metal nanoparticles. This was performed with a JEOL ARM 200F microscope, equipped with a cold field emission gun and a CEOS aberration corrector of the objective lens, operated at $200 \mathrm{kV}$ [41]. Statistical analysis of the metal particle size distribution (PSD) in reduced samples was obtained by counting more than 200 particles, using the software

Image J. The average particle diameter was deduced from the formula $d_{m}=\sum n_{i} d_{i}{ }^{3} / \sum n_{i} d_{i}{ }^{2}$, where $n_{i}$ is the number of the particles of diameter $d_{i}$. The detection limit of the particles was $0.5 \mathrm{~nm}$ at $200 \mathrm{kV}$. The average particle sizes were measured from STEM-HAADF assuming 
spherical shapes and the mean $\mathrm{Ni} / \mathrm{Zn}$ atomic ratios were obtained from the EDS analyses of a set of individual particles.

After some specific catalytic tests, thermogravimetric analysis (TG) of the catalysts was performed using a Seiko 320 thermobalance. Around $20 \mathrm{mg}$ of catalysts were heated under air (100 $\mathrm{ml} \mathrm{min}^{-1}$ ) from room temperature to $900{ }^{\circ} \mathrm{C}$ with a heating rate of $5{ }^{\circ} \mathrm{C} \mathrm{min}^{-1}$.

\subsection{Acetylene and Butadiene selective hydrogenation reactions}

The reaction of acetylene hydrogenation was carried out with $200 \mathrm{mg}$ of a mixture containing $50 \mathrm{mg}$ of catalysts $(0.5 \mathrm{wt} \% \mathrm{Ni}$ and various $\mathrm{Ni} / \mathrm{Zn}$ ratios $)$ and $150 \mathrm{mg}$ of $\mathrm{SiC}$ in a plug-flow microreactor ( $4 \mathrm{~mm}$ of internal diameter). The particle size of powder of both catalysts and $\mathrm{SiC}$ support was controlled by sieving between 125 and $200 \mu \mathrm{m}$. The ex situ calcined catalysts were activated in situ under pure $\mathrm{H}_{2}\left(100 \mathrm{~mL} \mathrm{~min}{ }^{-1}\right)$ from $\mathrm{RT}$ to $450{ }^{\circ} \mathrm{C}(3$ ${ }^{\circ} \mathrm{C} \min ^{-1}$ ) then $2 \mathrm{~h}$ at $450{ }^{\circ} \mathrm{C}$. After activation and cooling down to $100{ }^{\circ} \mathrm{C}$ under $\mathrm{H}_{2}$, the reaction mixture consisting of $2 \%$ acetylene and $20 \%$ hydrogen in He was introduced with a total flow rate of $100 \mathrm{~mL} \mathrm{~min}$, which corresponded to a space velocity of $30 \mathrm{~L} \mathrm{~g}^{-1} \mathrm{~h}^{-1}$. The reaction temperature was then increased at the rate of $1{ }^{\circ} \mathrm{C} / \mathrm{min}$ from $100{ }^{\circ} \mathrm{C}$ to a final temperature between $165-175^{\circ} \mathrm{C}$ depending on the catalyst, in order to achieve an acetylene conversion in the range $90-98 \%$. The reaction was maintained at the final temperature for about $20 \mathrm{~h}$ in order to monitor the stability of the catalysts. Gas Chromatography (GC) analysis of the reaction reactant and products (acetylene, ethylene, ethane) was performed using a micro-GC Varian 4900 every $10 \mathrm{~min}$. The formation of C-C coupling products (oligomers) was not detected by GC but the selectivity to such oligomers was calculated on the basis of the mole balance between the amount of acetylene consumed and the one of ethylene and ethane produced (see supplementary information).

The reaction of butadiene hydrogenation in an excess of propene was carried out on 100 
$\mathrm{mg}$ of a mixture containing $10 \mathrm{mg}$ of catalysts $(0.5 \mathrm{wt} \% \mathrm{Ni}$ with various $\mathrm{Ni} / \mathrm{Zn}$ ratios $)$ and 90 mg of pure $\mathrm{TiO}_{2}$ support (sieve fraction, $125-200 \mu \mathrm{m}$ ) in a plug flow microreactor $(4 \mathrm{~mm}$ of internal diameter), either for temperature-programmed reaction or for isothermal reaction. The ex situ calcined catalysts were activated in situ, under pure $\mathrm{H}_{2}\left(100 \mathrm{~mL} \mathrm{~min}^{-1}\right)$ from $\mathrm{RT}$ to 450 ${ }^{\circ} \mathrm{C}\left(3{ }^{\circ} \mathrm{C} \min ^{-1}\right)$ then held for $2 \mathrm{~h}$ at the final temperature. After cooling down to room temperature under $\mathrm{H}_{2}$, the reactor was immersed into a water bath connected to a temperature controller and the reaction mixture consisting of $0.3 \%$ butadiene, $30 \%$ propene and $20 \%$ hydrogen in He was introduced with a total flow rate of $50 \mathrm{~mL} \mathrm{~min}^{-1}$, which corresponded to a space velocity of $30 \mathrm{~L} \mathrm{~g}^{-1} \mathrm{~h}^{-1}\left(\mathrm{GHSV}=20,000 \mathrm{~h}^{-1}\right)$.

In the case of the temperature-programmed reaction, the analysis of the reaction mixture at the outlet of the reactor was done every $5{ }^{\circ} \mathrm{C}$ from $10{ }^{\circ} \mathrm{C}$ to $80{ }^{\circ} \mathrm{C}$ after stabilization at each temperature for $15 \mathrm{~min}$. The analysis of the reaction products was performed by gas chromatography (Perichrom PR 2100, FID detector). In the case of the isothermal reaction, after in situ reduction at $450{ }^{\circ} \mathrm{C}$ for $2 \mathrm{~h}$, the reactor was also immersed into the water bath at a given temperature, and the reaction was performed during $20 \mathrm{~h}$. It was monitored at a specific reaction temperature, to provide a similar initial butadiene conversion around $90 \%$ for all the catalysts, with a GC analysis performed every $15 \mathrm{~min}$. As mentioned in [42], tests were made to attest that under the catalytic conditions described and at low conversion, internal and external diffusion limitations could be neglected.

The detailed calculations of the conversions, selectivities for the various reactants and products, concentration in alkanes, activities and TOF can be found in the supplementary information. 


\section{RESULTS AND DISCUSSION}

\subsection{Samples characterization}

The metals loadings in the as-prepared $\mathrm{Ni}$ and $\mathrm{Ni}-\mathrm{Zn}$ samples are summarized in Table 1, which shows that the final Ni loadings are close to the nominal ones while the $\mathrm{Zn}$ loadings are always slightly lower than the nominal ones.

Table 1: Experimental metal loadings in the $\mathrm{Ni}-\mathrm{Zn} / \mathrm{TiO}_{2}$ samples prepared by DPU determined by XRF and composition of the NiZn /bimetallic particles in $\mathrm{Ni}-\mathrm{Zn} / \mathrm{TiO}_{2}$ determined by EDS.

\begin{tabular}{|c|c|c|c|c|c|c|c|c|c|}
\hline \multirow{2}{*}{ Catalysts } & \multicolumn{2}{|c|}{ Nominal loadings } & \multicolumn{3}{|c|}{$\begin{array}{c}\text { Experimental loadings for as- } \\
\text { prepared samples }\end{array}$} & \multicolumn{3}{|c|}{$\begin{array}{l}\text { Experimental loadings after } \\
\text { reduction under } \mathrm{H}_{2} \text { at } 450{ }^{\circ} \mathrm{C}\end{array}$} & \multirow{2}{*}{$\begin{array}{c}\text { Average } \mathrm{Ni} / \mathrm{Zn} \\
\text { atomic ratios } \\
\text { in } \\
\text { nanoparticles } \\
\text { from EDS } \\
\end{array}$} \\
\hline & $\begin{array}{c}\mathrm{Zn} \\
(\mathbf{w t} \%)\end{array}$ & $\begin{array}{c}\mathrm{Ni} \\
(\mathrm{wt} \%)\end{array}$ & $\underset{(w t \%)}{Z n n}$ & $\begin{array}{c}\mathrm{Ni} \\
(\mathrm{wt} \%)\end{array}$ & $\begin{array}{l}\mathrm{Ni} / \mathrm{Zn} \\
\text { atomic } \\
\text { ratios }\end{array}$ & $\begin{array}{c}\mathrm{Zn} \\
(\mathbf{w t} \%)\end{array}$ & $\begin{array}{c}\mathrm{Ni} \\
(\mathbf{w t} \%)\end{array}$ & $\begin{array}{l}\mathrm{Ni} / \mathrm{Zn} \\
\text { atomic } \\
\text { ratios }\end{array}$ & \\
\hline $\mathbf{N i}$ & - & 0.5 & - & 0.54 & - & & 0.54 & & - \\
\hline NiZn1 & 0.5 & 0.5 & 0.45 & 0.57 & 1.4 & 0.37 & 0.56 & 1.7 & 12 \\
\hline NiZn3 & 1.5 & 0.5 & 1.35 & 0.6 & 0.5 & 1.02 & 0.61 & 0.7 & 3.3 \\
\hline NiZn5 & 2.5 & 0.5 & 2.30 & 0.65 & 0.3 & 1.33 & 0.65 & 0.55 & 1.8 \\
\hline
\end{tabular}

The temperature for the reduction of calcined $\mathrm{Ni}-\mathrm{Zn} / \mathrm{TiO}_{2}$ was selected according to the results of temperature programmed reduction under $\mathrm{H}_{2}\left(\mathrm{TPR}-\mathrm{H}_{2}\right)$ presented in Figure 1. For comparison, TPR of calcined $0.5 \mathrm{wt} \% \mathrm{Zn} / \mathrm{TiO}_{2}$ is also included in Figure 1 and shows no reduction peaks in the range $50-550{ }^{\circ} \mathrm{C}$. The maximum temperature for TPR was set at $550{ }^{\circ} \mathrm{C}$ to avoid the contamination of the TPR equipment with volatile $\mathrm{Zn}^{0}[43-46]$. For the $\mathrm{Ni} / \mathrm{TiO}_{2}$ sample, two reduction peaks can be observed at about $400{ }^{\circ} \mathrm{C}$ and $530{ }^{\circ} \mathrm{C}$, similar to previous TPR results on $\mathrm{Ni} / \mathrm{TiO}_{2}$ samples prepared by $\left[\mathrm{Ni}\left(\mathrm{NH}_{3}\right)_{6}\right]^{2+}$ adsorption [47]. For the $\mathrm{Ni}-\mathrm{Zn} / \mathrm{TiO}_{2}$ samples, the reduction temperatures shift to higher values with increasing $\mathrm{Zn}$ loading, leaving only the low reduction temperature peak visible. To verify whether all the $\mathrm{Ni}^{2+}$ ions were reduced in the low temperature range $\left(350-475^{\circ} \mathrm{C}\right)$, the percentage of $\mathrm{Ni}^{2+}$ reduction in the first reduction peak of the sample was calculated by using the TPR of pristine $\mathrm{NiO}$ as a reference and the results are summarized in Table $\mathrm{S} 1$. It appears that almost all the $\mathrm{Ni}^{2+}$ species were 
reduced to metallic $\mathrm{Ni}$ in the temperature range below $500{ }^{\circ} \mathrm{C}$. As a consequence, the high temperature peak observed for $\mathrm{Ni} / \mathrm{TiO}_{2}$ probably corresponds to the reduction of $\mathrm{TiO}_{2}$ support, as reported by Geus et al. [48] who found that the total hydrogen consumption was larger than that required for full reduction of nickel ions in $\mathrm{Ni} / \mathrm{TiO}_{2}$ samples reduced up to $900{ }^{\circ} \mathrm{C}$. Based on Figure 1, a temperature of $450^{\circ} \mathrm{C}$ with a $2 \mathrm{~h}$-plateau was selected for sample activation before characterisation and catalytic reaction. Considering the low melting temperature of metallic $\mathrm{Zn}$ $\left(420^{\circ} \mathrm{C}\right)$, the metal loadings were also determined by XRF after reduction at $450{ }^{\circ} \mathrm{C}$. Table 1 shows a noticeable decrease of the zinc content, that can be related to the partial evaporation of this element in such a temperature and pressure range $[49,50]$. Similar $\mathrm{Zn}$ decreases was also observed and discussed during the reduction $\mathrm{Cu}-\mathrm{Zn}$ catalysts in a former paper [26]. Therefore, the $\mathrm{Ni} / \mathrm{Zn}$ ratios obtained after the reduction treatment are significantly higher than the nominal ones.

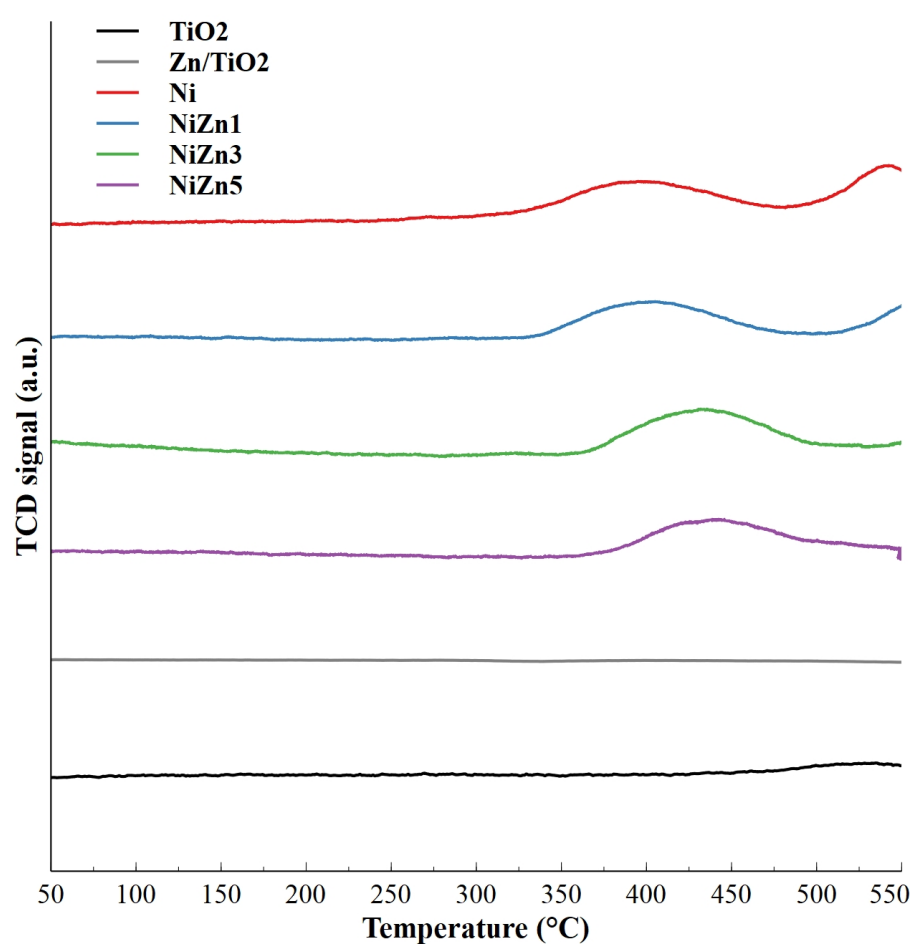

Figure 1. TPR of calcined $\mathrm{Ni} / \mathrm{TiO}_{2}, \mathrm{Zn} / \mathrm{TiO}_{2}$ and $\mathrm{Ni}-\mathrm{Zn} / \mathrm{TiO} 2$ catalysts with bare $\mathrm{TiO}_{2}$ as a reference 
Figure 2 shows the XRD patterns of $0.5 \mathrm{wt} \% \mathrm{Ni}-\mathrm{Zn} / \mathrm{TiO}_{2}$ samples in the range $40-46^{\circ}$ after calcination at $400{ }^{\circ} \mathrm{C}$, followed by reduction at $450{ }^{\circ} \mathrm{C}$. It is not clearly different from the XRD diagram of $\mathrm{TiO}_{2}$ support plotted on the same figure. Only the NiZn5 sample shows an additional peak $\left(43.3^{\circ}\right)$ to the ones of the support. It is significantly shifted from the main peak of metallic $\mathrm{Ni}$ expected at $44.5^{\circ}$ (JCPDS: \#71-4655), and corresponds to the one of Ni-Zn alloy (43.3 JCPDS card: \# 72-2668). According to the information given on the JCPDS card and the relationship between the crystal lattice spacing and the composition of Ni-Zn alloy [51], the Ni$\mathrm{Zn}$ alloy seems to correspond to $\beta_{1}-\mathrm{NiZn}$ alloy with 50 at $\% \mathrm{Ni}\left(\mathrm{Ni}_{1} \mathrm{Zn}_{1}\right.$ alloy). Using the Scherrer's equation, the Ni-Zn alloy crystallite size was estimated to be about $6 \mathrm{~nm}$ for NiZn5 but the margin of error on this value is high due to the weak intensity of the peak. For the other $\mathrm{Ni}-\mathrm{Zn} / \mathrm{TiO}_{2}$ samples, the crystallite size of metallic $\mathrm{Ni}$ or $\mathrm{Ni}-\mathrm{Zn}$ phase may be too small to be detected by XRD, or the peak could overlap with the broad $\mathrm{TiO}_{2}$ peak at $44^{\circ}$.

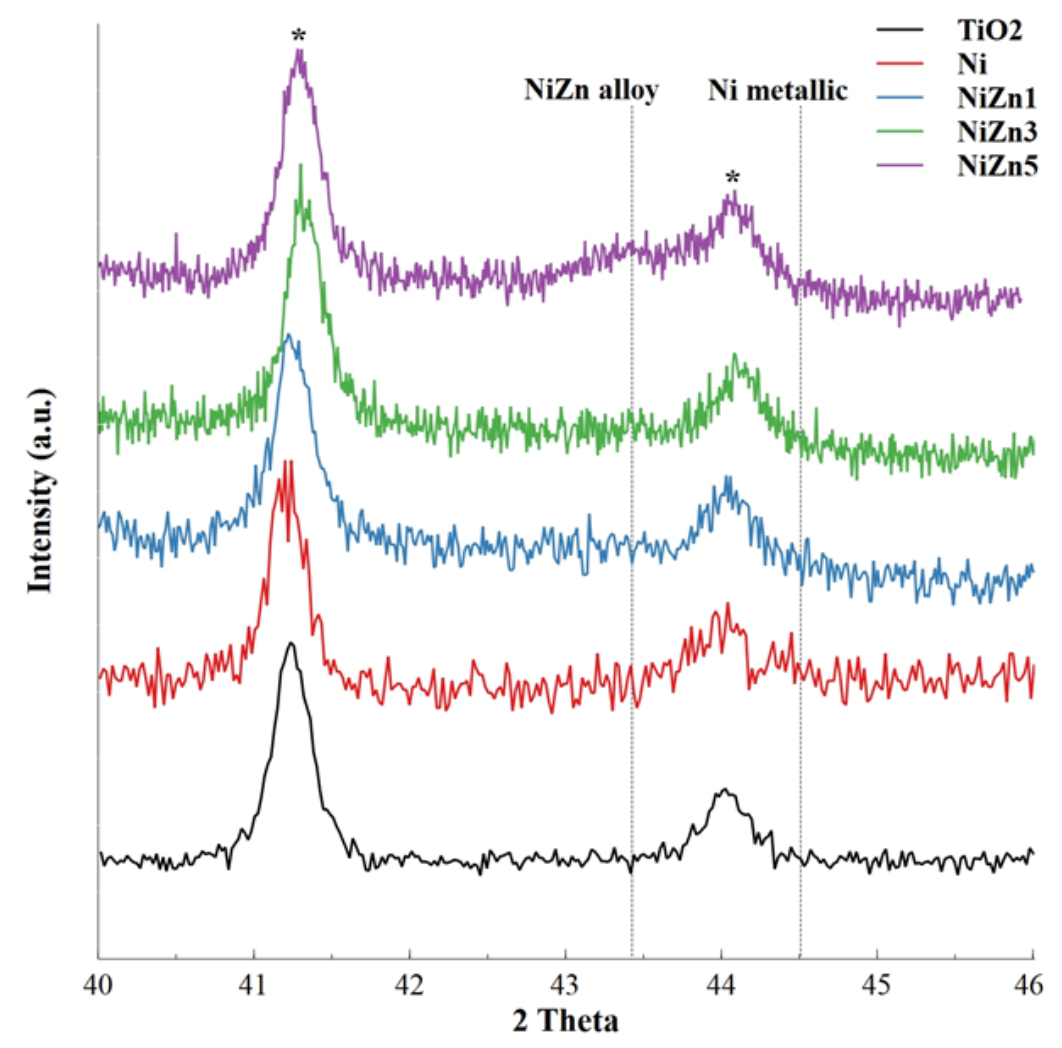

Figure 2. XRD patterns of the calcined-reduced $\mathrm{Ni}-\mathrm{Zn} / \mathrm{TiO}_{2}$ samples $(0.5 \mathrm{wt} \% \mathrm{Ni})$ with bare $\mathrm{TiO}_{2}$ as a reference. * Rutile $\mathrm{TiO}_{2}$ (JCPDS: 01-086-0147); NiZn alloy peak position from JCPDS: 01-072-2668; metallic Ni peak position from JCPDS: 00004-0850 
The various samples prepared with $0.5 \mathrm{wt} \% \mathrm{Ni}$ were imaged by STEM-HAADF after calcination at $400{ }^{\circ} \mathrm{C}$ then reduction at $450{ }^{\circ} \mathrm{C}$ (Figure 3). The average particle size deduced from the particle size distribution is included in Table 2. For the $0.5 \mathrm{wt} \% \mathrm{Ni} / \mathrm{TiO}_{2}$ sample (Figure 3a), small particles are visible with an average particle size of $3.2 \mathrm{~nm}$. The particle size slightly increases when $\mathrm{Zn}$ is present to $3.4,3.8$ and $4.1 \mathrm{~nm}$ for the NiZn1, NiZn3 and NiZn5 samples, respectively and the addition of $\mathrm{Zn}$ also broadens the size distribution in the Ni$\mathrm{Zn} / \mathrm{TiO}_{2}$ samples (Figure 3b-d). For instance, the particles size distribution is in the range of 1 to $6 \mathrm{~nm}$ for NiZn1 whereas it is of 1 to $9 \mathrm{~nm}$ for NiZn5.
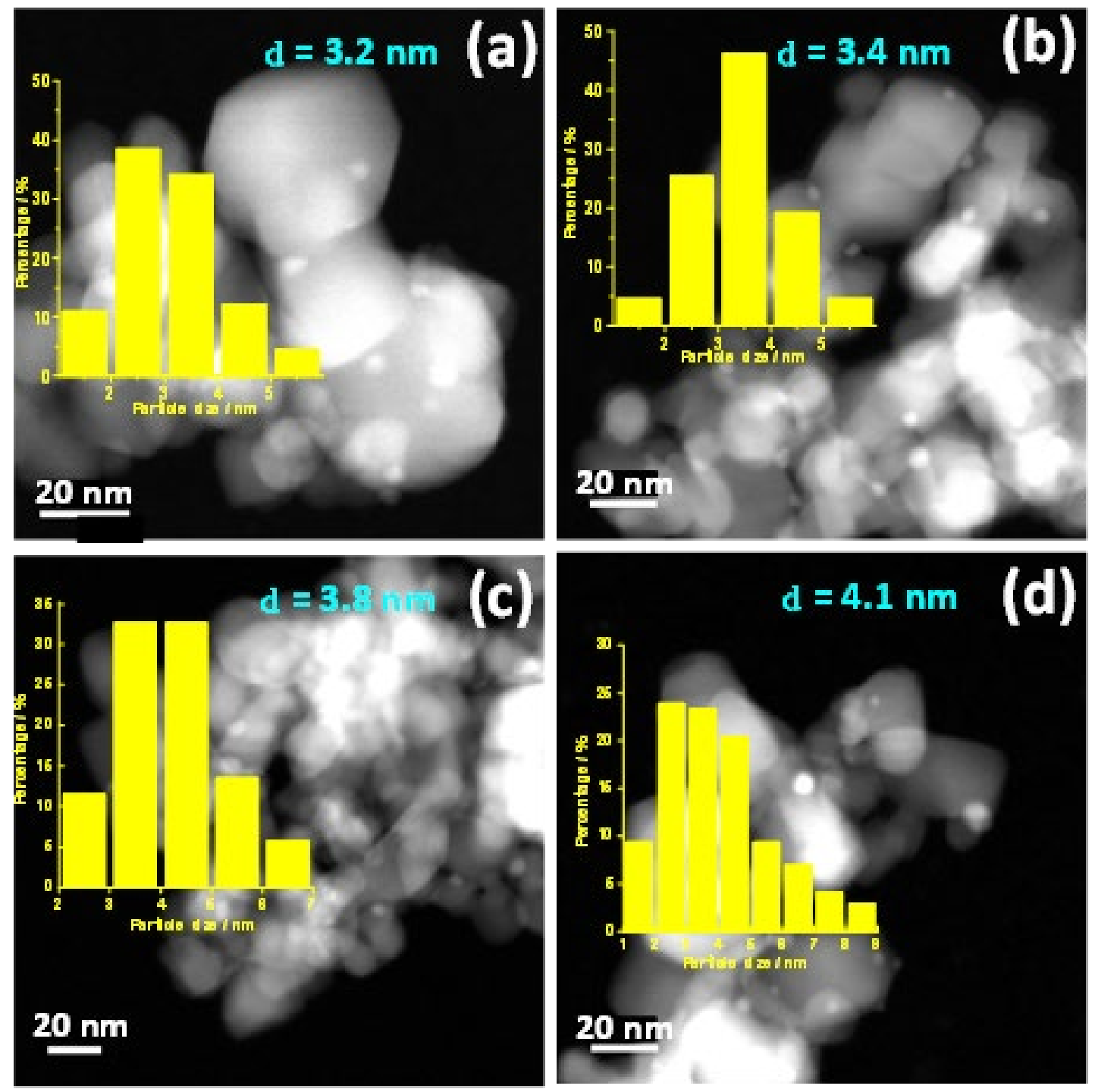

Figure 3. STEM-HAADF images of the calcined-reduced $\mathrm{Ni}-\mathrm{Zn} / \mathrm{TiO}_{2}$ samples $(0.5 \mathrm{wt} \% \mathrm{Ni})$ with the particle size distribution: Ni (a); NiZn1 (b); NiZn3 (c); NiZn5 (d) 
Table 2: Size of the NiZn /bimetallic particles in $\mathrm{Ni}-\mathrm{Zn} / \mathrm{TiO}_{2},(0.5 \mathrm{wt} \% \mathrm{Ni})$ determined by electron microscopy and catalytic activity and TOF in acetylene hydrogenation and butadiene selective hydrogenation in excess of propene.

\begin{tabular}{|c|c|c|c|c|c|}
\hline \multirow{2}{*}{ Sample } & \multirow{2}{*}{$\begin{array}{l}\text { Average metal particle size } \\
\quad \text { (nm, based on TEM) }\end{array}$} & \multicolumn{2}{|c|}{ Acetylene hydrogenation } & \multicolumn{2}{|c|}{$\begin{array}{c}\text { Butadiene selective hydrogenation in } \\
\text { excess of propene }\end{array}$} \\
\hline & & $\begin{array}{c}\text { Activity at } 130{ }^{\circ} \mathrm{C} \\
\left(\times 10^{-4} \text { mol }_{\text {acetylene }} \mathrm{s}^{-1} \mathrm{~g}_{\mathrm{Ni}}^{-}\right. \\
1)\end{array}$ & $\begin{array}{c}\text { TOF } \\
\text { at } 130{ }^{\circ} \mathrm{C} \\
\left(\mathrm{s}^{-1}\right)^{\mathrm{b}}\end{array}$ & $\begin{array}{c}\text { Activity at } 20^{\circ} \mathrm{C} \\
\left(\times 10^{-4} \text { mol }_{\text {butadiene }} \mathbf{s}^{-1} \mathrm{~g}_{\mathrm{Ni}^{-1}}\right)\end{array}$ & $\begin{array}{c}\text { TOF } \\
\text { at } 20^{\circ} \mathrm{C} \\
\left(\mathbf{s}^{-1}\right)^{\mathrm{b}}\end{array}$ \\
\hline $\mathbf{N i}$ & 3.2 & 26 & 0.5 & 16 & 0.3 \\
\hline NiZn1 & 3.4 & 16 & 0.5 & 9 & 0.3 \\
\hline NiZn3 & 3.8 & 12 & 0.75 & 10 & 0.6 \\
\hline NiZn5 & $4.1 / 5.8^{\mathrm{a}}$ & 12 & 0.9 & 4 & 0.25 \\
\hline
\end{tabular}

a: crystallite size estimated from XRD

b: all the metal particles are assumed as spherical shape

Since Ni-Zn alloy formation was only detected by XRD for NiZn5, STEM-HAADF coupled with Energy Dispersive X-ray spectrometry (EDS) was performed on a series of individual particles in the three $\mathrm{Ni}-\mathrm{Zn} / \mathrm{TiO}_{2}$ samples to determine the $\mathrm{Ni} / \mathrm{Zn}$ atomic ratios as a function of the nanoparticle size. The EDS results in Figure 4 show that Ni-Zn alloys are formed in all the particles analysed for the three samples and that the $\mathrm{Ni} / \mathrm{Zn}$ atomic ratio increases with the decrease in particle size in each of the $\mathrm{Ni}-\mathrm{Zn} / \mathrm{TiO}$ samples. The average $\mathrm{Ni} / \mathrm{Zn}$ atomic ratios decrease with increasing $\mathrm{Zn}$ loading from 12 in NiZn1 $\left(\mathrm{Ni} / \mathrm{Zn}=1.69\right.$ after reduction at $\left.450{ }^{\circ} \mathrm{C}\right)$ to 1.8 in $\mathrm{NiZn} 5(\mathrm{Ni} / \mathrm{Zn}=0.54$ after reduction) (Table 1$)$. It is worth to note that the composition of the Ni-Zn nanoparticles determined by EDS suggests that only a fraction of zinc present in the samples is alloyed with nickel, implying that another fraction might be present on the support surface. The nature of these residual $\mathrm{Zn}$ species is unknown, the presence of $\mathrm{ZnO}$ being 
not evidenced by XRD (Figure S1). However, it is also possible that Zn sublimates under exposure to the electron beam during the EDS analysis as previously proposed for carbon supported Pd-Zn bimetallic particles [52], which may result in a strong underestimation of the Zn content.
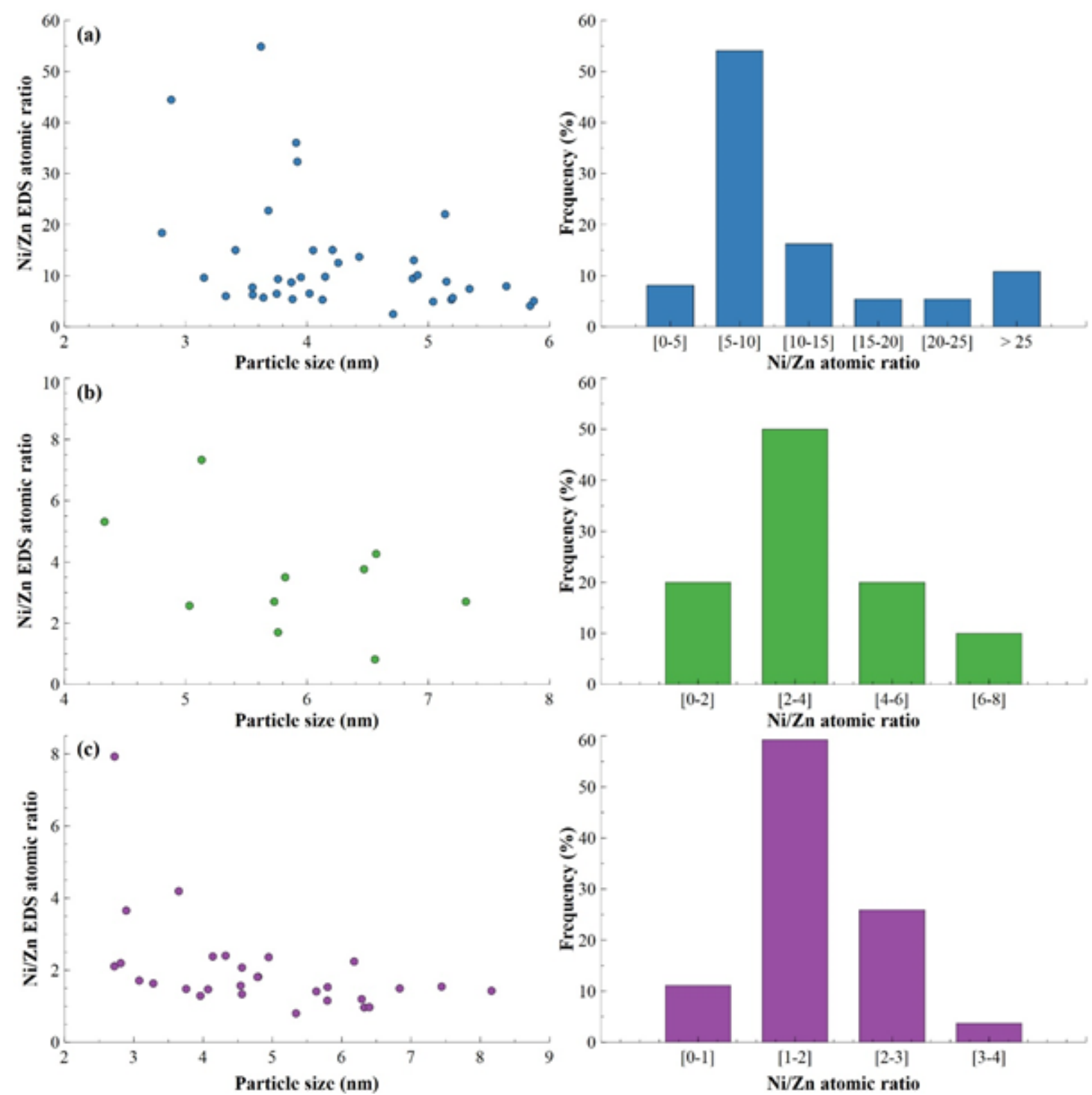

Figure 4. $\mathrm{Ni} / \mathrm{Zn}$ atomic ratio determined by EDS analysis as a function of particle size (left panel) and $\mathrm{Ni} / \mathrm{Zn}$ atomic ratio distribution (right panel) for the calcined-reduced $\mathrm{Ni}-\mathrm{Zn} / \mathrm{TiO}_{2}$ samples (0.5 wt\% Ni): NiZn1 (a); NiZn3 (b); NiZn5 (c) 


\subsection{Hydrogenation of pure acetylene and hydrogenation of butadiene in an excess of propene}

\subsubsection{Hydrogenation of pure acetylene}

The hydrogenation of acetylene was studied in the absence of an excess of alkene, examining the selectivity to ethylene, ethane and oligomers, first by temperature programmed reaction from $100{ }^{\circ} \mathrm{C}$ to $165-175^{\circ} \mathrm{C}$ (range of temperature allowing to reach $90-98 \%$ acetylene conversion for all the catalysts). The final temperature was then kept constant for about $24 \mathrm{~h}$ in order to evaluate the stability of the $\mathrm{Ni}$ and NiZn samples. One can remind that the catalytic beds contain the same mass of $\mathrm{Ni} . \mathrm{Zn}(2.5 \mathrm{wt} \%) / \mathrm{TiO}_{2}$ does not present any activity in the temperature range $100-200{ }^{\circ} \mathrm{C}$ (not shown)

Figure $5 \mathrm{a}$ and Table 2 shows that the $\mathrm{Ni} / \mathrm{TiO}_{2}$ catalyst is the most active catalyst and that the addition of $\mathrm{Zn}$ decreases the acetylene conversion. NiZn3 is the least active one among the bimetallic catalysts. However, the TOF values calculated at $130{ }^{\circ} \mathrm{C}$ seems to indicate that nickel in the bimetallic $\mathrm{Ni}-\mathrm{Zn}$ catalysts is more active than in the monometallic $\mathrm{Ni} / \mathrm{TiO}_{2}$, provided that the values are meaningful (see supplementary information for detailed calculations and hypotheses). The evolution of the selectivity to ethylene and ethane as a function of the acetylene conversion, reported in Figures $5 \mathrm{~b}$ and $5 \mathrm{c}$, shows that the selectivity to both products is rather constant up to a $\mathrm{C}_{2} \mathrm{H}_{2}$ conversion of $80 \%$, the bimetallic $\mathrm{Ni}-\mathrm{Zn}$ catalysts being clearly more selective to ethylene (70-80\%) than Ni (less than 50\%) (Figure 5b). At acetylene conversion higher than $80 \%$, the selectivity to ethane starts to increase, especially for NiZn1 (Figure 5c). The monometallic Ni catalyst has a high selectivity to oligomers (above $40 \%$ ) whatever the $\mathrm{C}_{2} \mathrm{H}_{2}$ conversion whereas the oligomers formation continuously decreases for all the bimetallic catalysts (Figure S2). 

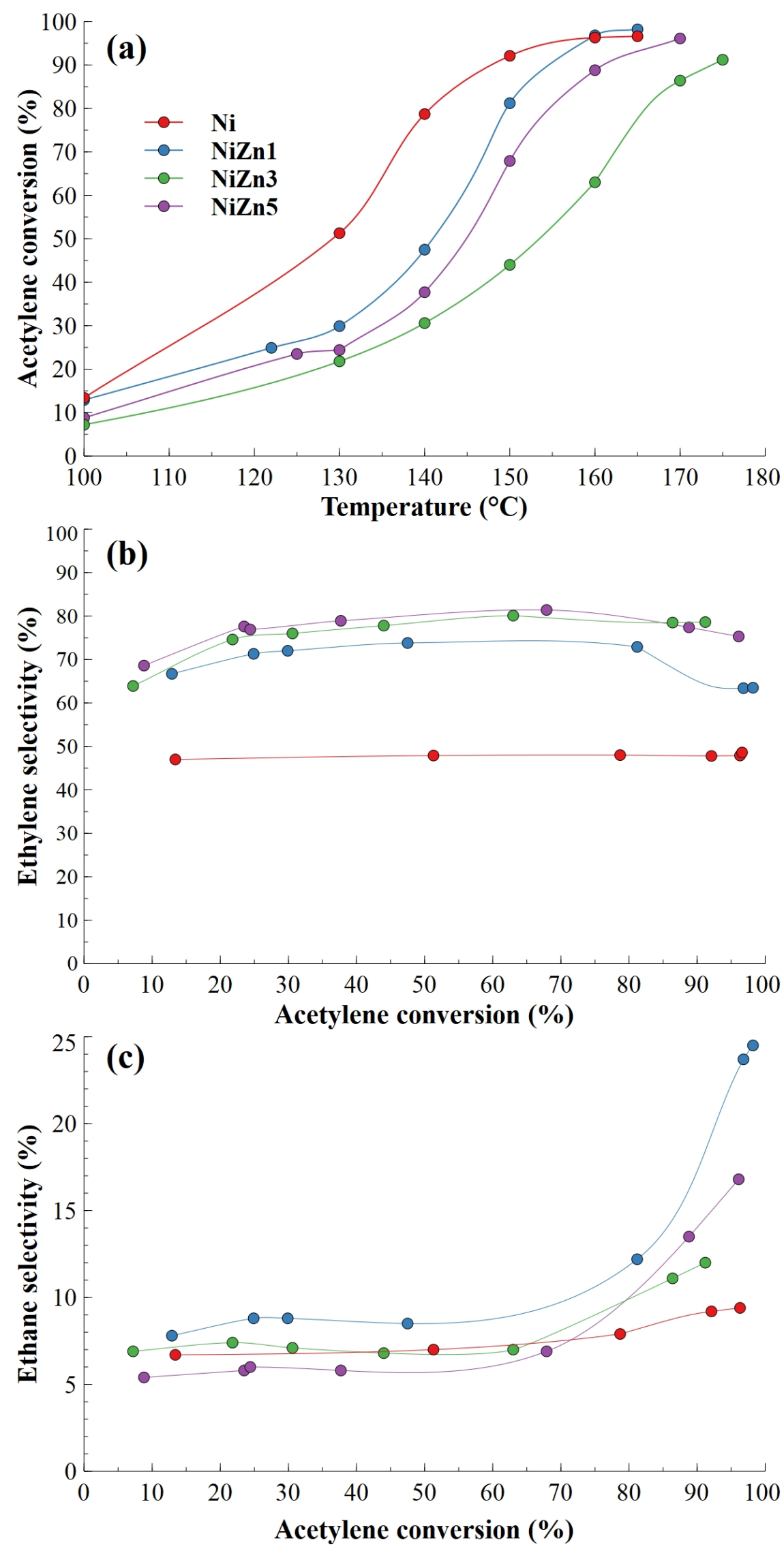

Figure 5. Evolution of the acetylene conversion with reaction temperature (a) and evolution of the selectivity to ethylene (b) and ethane (c) as a function of acetylene conversion during temperature programmed reaction of acetylene hydrogenation for the calcined then reduced $\mathrm{Ni}$ and $\mathrm{Ni}-\mathrm{Zn} / \mathrm{TiO}_{2}$ catalysts $(0.5 \mathrm{wt} \% \mathrm{Ni})(50 \mathrm{mg}$ of catalyst diluted with $150 \mathrm{mg} \mathrm{SiC})$. 
After reaching an acetylene conversion in the range $90-98 \%$ for all the samples, the stability of the catalysts was monitored with time on stream at constant temperature (between 165 and 175 ${ }^{\circ} \mathrm{C}$, depending on the catalyst) (Figure 6a). The monometallic $\mathrm{Ni} / \mathrm{TiO}_{2}$ is the most stable catalyst, with a $\mathrm{C}_{2} \mathrm{H}_{2}$ conversion above $80 \%$ even after $22 \mathrm{~h}$ of reaction. Bimetallic $\mathrm{NiZn} 1$ and NiZn3 samples deactivate with time in a similar way, with a sensible loss of conversion in the first $10 \mathrm{~h}$ on stream before continuing with a slow decrease of conversion with time. NiZn5 shows a different profile of deactivation with slower initial but continuous and almost linear loss of activity with time. Given the relatively low reaction temperatures used, the hypothesis of particle sintering during the reaction can be discarded to explain the observed deactivations. Regarding the selectivity, Figure $6 \mathrm{~b}$ presents the evolution of the selectivity to ethylene with time on stream for the whole experiments. It is interesting to note that the selectivity to $\mathrm{C}_{2} \mathrm{H}_{4}$ remains nearly constant for all the catalysts above $5 \mathrm{~h}$ reaction, even the ones that significantly deactivate. The same trends are observed for the selectivity to ethane and oligomers (Figure $\mathrm{S} 3$ ). It also appears that the addition of $\mathrm{Zn}$ to $\mathrm{Ni}$ increases the selectivity to ethylene, with an effect more marked for the catalyst containing the higher amount of $\mathrm{Zn}$. Figure $6 \mathrm{c}$ presents the average selectivities to ethylene, ethane and oligomers calculated between 5 and $22 \mathrm{~h}$ of reaction for all the catalysts. The increasing selectivity to ethylene from about $55 \%$ for $\mathrm{Ni} / \mathrm{TiO}_{2}$ up to $75-85 \%$ for the $\mathrm{Ni}-\mathrm{Zn} / \mathrm{TiO}_{2}$ catalysts is essentially at the expense of the one to oligomers as the selectivity to ethane is almost equivalent and remains around $8-9 \%$ for all the catalysts. 

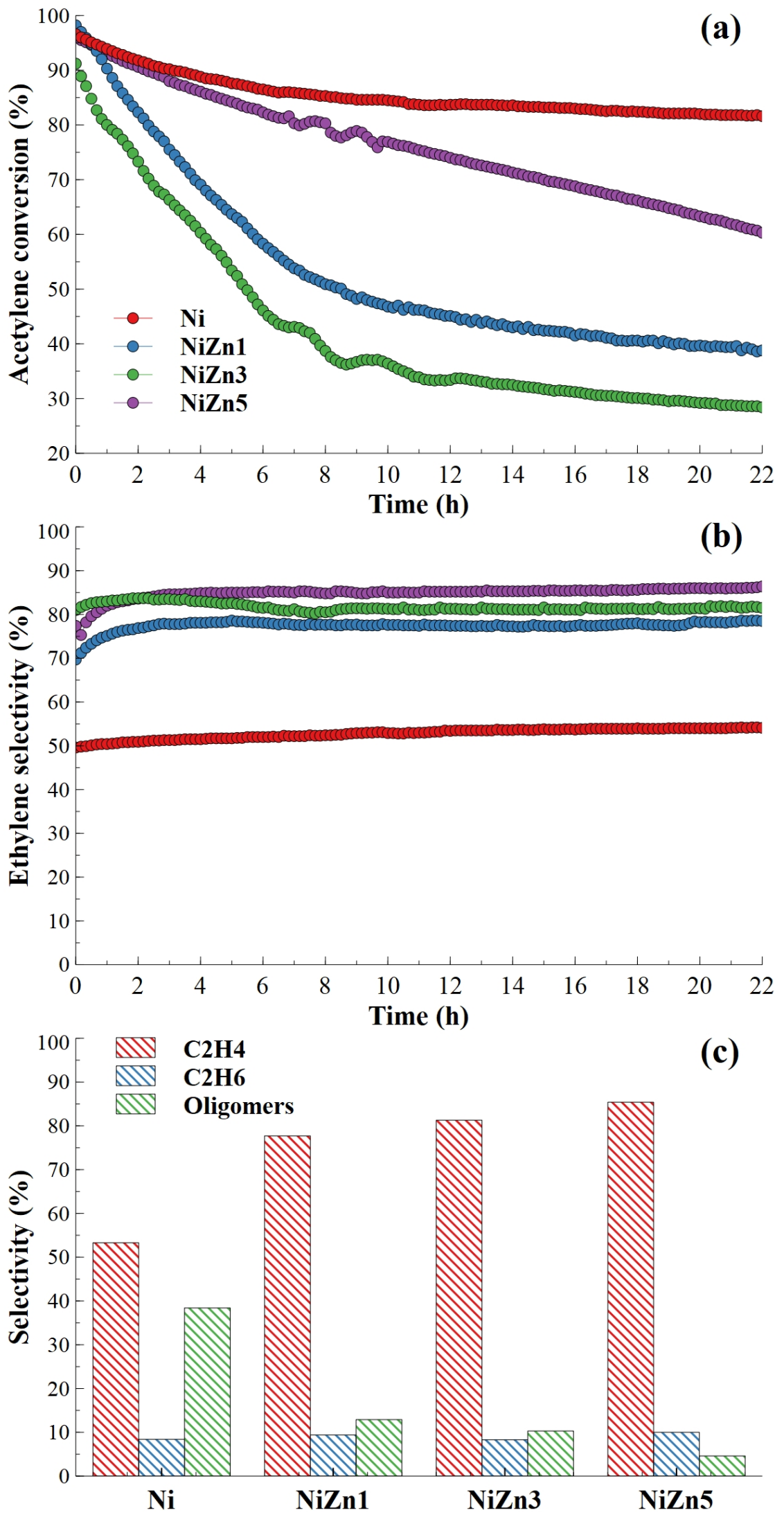

Figure 6. Evolution of the acetylene conversion (a) and the selectivity to ethylene (b) during acetylene hydrogenation with time on stream at $165^{\circ} \mathrm{C}$ for $\mathrm{Ni}$ and NiZn1, $175{ }^{\circ} \mathrm{C}$ for NiZn3 and $170{ }^{\circ} \mathrm{C}$ for NiZn5. Average selectivities to ethylene, ethane and oligomers at pseudo-stable state (c) for the calcined then reduced $\mathrm{Ni}$ and $\mathrm{Ni}-\mathrm{Zn} / \mathrm{TiO}_{2}$ catalysts $(0.5 \mathrm{wt} \% \mathrm{Ni})(50 \mathrm{mg}$ of catalyst diluted with $150 \mathrm{mg} \mathrm{SiC}$ ). 
The lower activity of the $\mathrm{Zn}$-containing catalysts compared to the Ni counterparts is in line with what was previously observed for Ni-Zn systems in selective hydrogenation reactions [27, 53]. For acetylene hydrogenation, such a decrease in activity was ascribed to the lower acetylene adsorption energy on $\mathrm{Ni}-\mathrm{Zn}$ intermetallic compounds [27], which results from the substitution of $\mathrm{Ni}$ atoms by $\mathrm{Zn}$ ones at the surface of the bimetallic nanoparticles. Ni substitution by a second metal, such as $\mathrm{Zn} \mathrm{[25]} \mathrm{and} \mathrm{Pt} \mathrm{[54],} \mathrm{was} \mathrm{proposed} \mathrm{to} \mathrm{modify} \mathrm{the} \mathrm{electronic} \mathrm{properties} \mathrm{of} \mathrm{surface}$ $\mathrm{Ni}$ atoms and thus the strength of adsorption of reactants [55]. It was also proposed recently that the $\mathrm{Zn}$ atoms prefer to replace the $\mathrm{Ni}$ atoms at low coordination sites (corners, edges or defects) of the particles surface $[56,57]$. As the low coordination Ni sites are expected to bind unsaturated compounds more strongly than terrace sites [58], their replacement by Zn atoms could also contribute to lower the activity of bimetallic samples.

In the case of selective hydrogenation of acetylene in the presence of ethylene over bulk intermetallic Ni-Zn compounds in a batch reactor [27], the formation of Ni-Zn alloys was also shown to result in a decrease in the oligomers formation and in an enhancement of the selectivity to ethylene. The lower acetylene adsorption energy, estimated from DFT calculations, on Ni-Zn alloys surface compared to pure Ni surface was considered as the primary cause for the decrease of the rate of carbon-carbon formation. Interestingly, another study from the same group revealed that when $\mathrm{Ni}-\mathrm{Zn}$ alloys was supported on $\mathrm{ZnO}$, resulting from high temperature reduction of $\mathrm{Ni} / \mathrm{ZnO}$ precursor, the selectivity to ethylene decreased at the benefit to the one to oligomers by comparison with a reference $\mathrm{Ni} / \mathrm{SiO}_{2}$ catalyst [28]. The authors assigned these observations to the negative role of the $\mathrm{ZnO}$ support, which favoured the acetylene oligomerization. This is not the case when the $\mathrm{Ni}-\mathrm{Zn}$ alloys are supported on $\mathrm{TiO}_{2}$, as the selectivity to oligomers decreases from $38 \%$ for Ni down to $5 \%$ for NiZn5. It is worth to note that the formation of a green oily liquid was clearly visible in the reactor containing 
$\mathrm{Ni} / \mathrm{TiO}_{2}$ when it was removed from the oven at the end of reaction but not in the case of Ni$\mathrm{Zn} / \mathrm{TiO}_{2}$ catalysts, for which only droplets were visible on the walls at the outlet of the reactor. Thermogravimetric analyses reported in Figure 7 were performed under air for the various catalysts after the stability tests (Figure 6). The highest weight loss $(15.5 \%)$ was observed for the monometallic Ni catalyst. The sequence of weight loss for the bimetallic Ni-Zn catalysts follows the deactivation profiles observed in Figure 6a, that is NiZn5, with the slowest deactivation rate, presents the lowest weight loss (8.2\%) whereas NiZn1 and NiZn3 have very close ones (around 10.5\%). All the samples show two peaks located around 300 and $390{ }^{\circ} \mathrm{C}$ in the differential thermogravimetric profiles (inset in Figure 7), which were previously assigned to heavy hydrocarbons adsorbed on the catalyst surface and to coke on or in the vicinity of Pd, respectively, for $\mathrm{Pd} / \mathrm{SiO}_{2}$ catalysts [59].

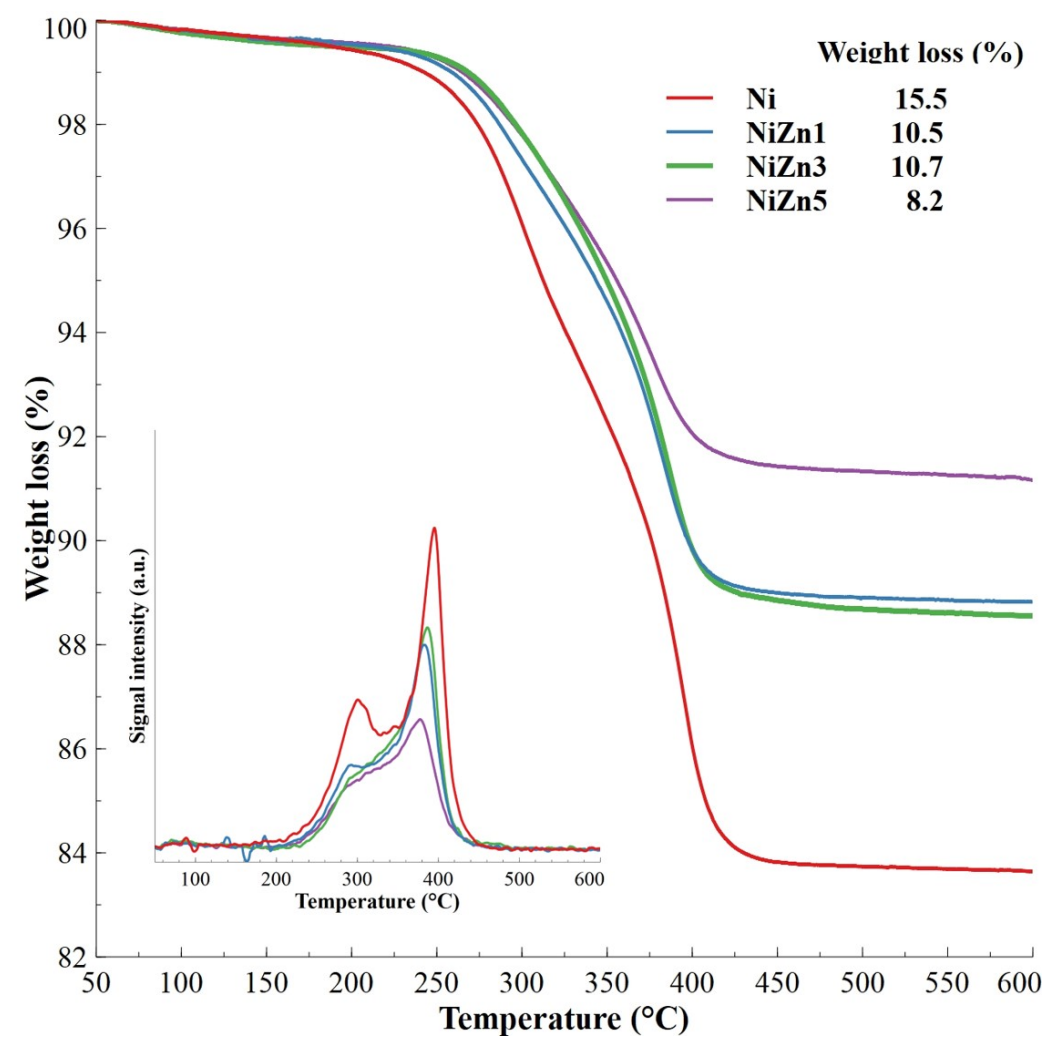

Figure 7. Thermogravimetric analyses performed in air after $20 \mathrm{~h}$ of acetylene stability test (Figure 6) for the calcined then reduced $\mathrm{Ni}$ and $\mathrm{Ni}-\mathrm{Zn} / \mathrm{TiO}_{2}$ catalysts. The catalysts were separated from $\mathrm{SiC}$ by crushing then sieving. Inset : Differential thermogravimetric analysis for the same samples. 
However, the stability of the catalysts is not directly correlated with the selectivity to oligomers. Indeed, $\mathrm{Ni} / \mathrm{TiO}_{2}$ is the most stable catalyst although it presents the highest selectivity to oligomers whereas the bimetallic Ni-Zn samples deactivate gradually with time while forming less oligomers. The effect of polymers formation, such as green oil in acetylene hydrogenation, on the catalyst stability is controversial in the literature. Catalysts deactivation can result from several causes involving various chemical, thermal and mechanical phenomena (i.e., poisoning, fouling, thermal degradation, vapour-solid and solid-solid reactions, and attrition/crushing) [60]. Green oil (paraffin and olefinic hydrocarbons in the $\mathrm{C}_{8}-\mathrm{C}_{24}$ range) is often considered as responsible for the deactivation of Pd based selective hydrogenation catalysts by reducing the surface area, blocking the active sites and inhibiting the adsorption and activation of the alkyne and $\mathrm{H}_{2}$ reactants $[61,62]$. However, the extent of the formation of such carbonaceous deposit is not always linked to the loss of activity of the catalysts, as limited deactivation was obtained for Pd based catalysts presenting a content of $36 \mathrm{wt} \%$ of carbonaceous deposit [63]. The deactivation of $\mathrm{Pd} / \mathrm{SiO}_{2}$ catalysts in acetylene hydrogenation was shown to occur in three stages $[59,62]$. In particular, in a first stage, large amount of relatively light green oil (up to $35 \mathrm{wt} \%$ ) is formed on the catalyst but acetylene can adsorb on such green oil and then be hydrogenated to ethylene by an hydrogen transfer mechanism. During this stage, the activity of the catalysts only slightly decreases. Moreover, a part of this light and volatile green oil can be hydrogenated and thus removed from the surface, provided that the hydrogen surface concentration is sufficient. As the carbonaceous deposits accumulate on the catalyst surface, polymerization to heavier green oil occurs in a second stage (up to $55 \mathrm{wt} \%$ ), which can move from the Pd surface to the support. This stage also results in a limited loss of conversion. The major part of the deactivation, in the third stage, was assigned to the blocking of the catalyst pores by the accumulation of green oil, which strongly limits the hydrogen diffusion to the active surface [62]. It is plausible that the same phenomenon occurs in the case of the $\mathrm{Ni} / \mathrm{TiO}_{2}$ catalyst and 
that the high $\mathrm{H}_{2} / \mathrm{C}_{2} \mathrm{H}_{2}$ molar ratio of 10 used in this study favours the hydrogenation of the light green oil formed, limiting its deactivation for this reaction time. Regarding the $\mathrm{Ni}-\mathrm{Zn} / \mathrm{TiO}_{2}$ catalysts, the formation of bimetallic Ni-Zn nanoparticles may decrease the surface hydrogen coverage, which makes it more difficult to hydrogenate the light green oil, leading to some early deactivation. However, it is difficult to explain the different deactivation behaviour of the various $\mathrm{Ni}-\mathrm{Zn} / \mathrm{TiO}_{2}$ catalysts on the single basis of the $\mathrm{Zn}$ content provided by XRF.

The small size of the acetylene molecule and the very strong interaction of the reaction intermediates with transition metal surfaces make its semi-hydrogenation highly challenging in terms of selectivity by comparison with other alkynes or dienes [64]. The supported Ni-Zn bimetallic system appears as a good candidate for this reaction as a rather high selectivity to ethylene can be achieved (above 80\%) even at high conversion as predicted in [25]. However, in line with what was previously demonstrated by Spanjers et al [27], the gain in selectivity to ethylene is due to the reduction of the amount of oligomers formed and not to the suppression of the overhydrogenation to ethane.

\subsubsection{Hydrogenation of butadiene in an excess of propene}

The catalytic performances of the $\mathrm{Ni}-\mathrm{Zn} / \mathrm{TiO}_{2}$ samples were also evaluated in the selective hydrogenation of butadiene in the presence of an excess of propene.

Figure 8a shows the evolution of the catalytic activity during temperature programmed reaction between 10 and $80{ }^{\circ} \mathrm{C} . \mathrm{Zn}(2.5 \mathrm{wt} \%) / \mathrm{TiO}_{2}$ does not present any activity in the temperature range $30-150{ }^{\circ} \mathrm{C}$ (not shown). As for acetylene hydrogenation, the monometallic $\mathrm{Ni} / \mathrm{TiO}_{2}$ samples is the most active. It presents the lowest full butadiene conversion temperature $\left(\mathrm{T}_{100 \%}\right)$, around $35^{\circ} \mathrm{C}$. The introduction of increasing amounts of $\mathrm{Zn}$ leads to an increase of the $\mathrm{T}_{100 \%}$, that is $45^{\circ} \mathrm{C}$ for $\mathrm{NiZn} 1$ and NiZn 3 and $50{ }^{\circ} \mathrm{C}$ for NiZn5. The activity (mol butadiene $\mathrm{s}^{-1} \mathrm{~g}_{\mathrm{Ni}}{ }^{-}$

${ }^{1}$ ) and turnover frequencies (TOF, $\mathrm{s}^{-1}$ ) calculated at $20{ }^{\circ} \mathrm{C}$ are listed in Table 2 (see 
supplementary information for detailed calculations). Among the bimetallic samples, NiZn3 shows the highest catalytic activity (TOF), the two others presenting very similar TOF values to monometallic $\mathrm{Ni} / \mathrm{TiO}_{2}$. Again, the difficulties concerning the precise determination of bimetallic nanoparticles composition make it necessary to take these values cautiously.

For the reaction of semi-hydrogenation of butadiene in the presence of an excess of propene, the catalytic selectivity to alkenes can be considered either from the side of the butenes (1butene, trans-2-butene and cis-2-butene) formation (Figure $8 b$ ) or from the side of the outlet alkanes (butane and propane) concentration (Figure 8c) (see supplementary information for detailed calculations). First, it can be seen from Figure 8-b,c that both monometallic Ni and bimetallic Ni-Zn catalysts have high selectivity to alkenes at temperature lower than $\mathrm{T}_{100 \%}$. Figure $8 \mathrm{~b}$ shows that all the catalysts exhibit a progressive decrease of the selectivity to butenes, which coincides with the increase in the selectivity to butane (not shown), as the reaction temperature becomes close to $\mathrm{T}_{100 \%}$. At butadiene conversion close to $100 \%$, NiZn3 and NiZn5 produce more alkanes than $\mathrm{Ni} / \mathrm{TiO}_{2}$ (this was also the case for acetylene hydrogenation (Figure $5 \mathrm{c})$ ), but the concentration of alkanes remains lower than $10 \%$, indicating that all the catalysts are very selective to alkenes (Figure $8 \mathrm{c}$ ).

The catalytic stability of the samples was compared at similar initial butadiene conversion (80$90 \%$, which also means at different reaction temperatures $\left(20\right.$ to $\left.35^{\circ} \mathrm{C}\right)$ (Figure $\left.9 \mathrm{a}\right)$. For the monometallic Ni catalyst, the butadiene conversion decreases to below $10 \%$ during the first 10 $\mathrm{h}$ of reaction at $20^{\circ} \mathrm{C}$. After an initial loss of activity in the first hours of reaction, the bimetallic $\mathrm{Ni}-\mathrm{Zn} / \mathrm{TiO}_{2}$ catalysts, especially the NiZn5 sample, present only limited deactivation at $25^{\circ} \mathrm{C}$ and $35^{\circ} \mathrm{C}$. 

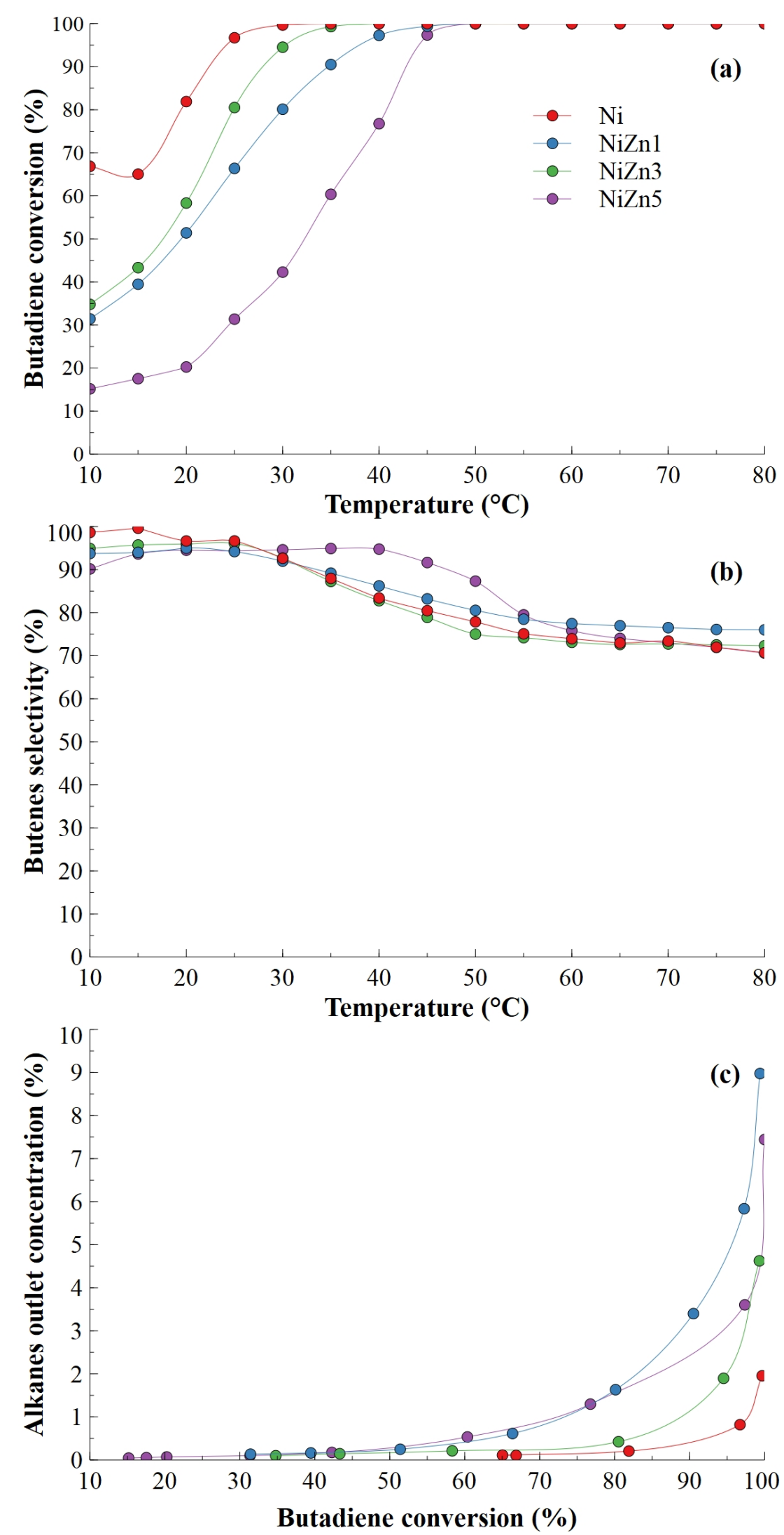

Figure 8. Evolution with reaction temperature of the butadiene conversion (a), the selectivity to butenes (1-butene + cis-2butene + trans-2-butene) (b) and outlet alkanes concentration as a function of butadiene conversion (c) for the calcined then reduced $\mathrm{Ni}$ and $\mathrm{Ni}-\mathrm{Zn} / \mathrm{TiO}_{2}$ catalysts $(0.5 \mathrm{wt} \% \mathrm{Ni})\left(10 \mathrm{mg}\right.$ of catalyst diluted with $\left.90 \mathrm{mg} \mathrm{\textrm {TiO } _ { 2 }}\right)$. 

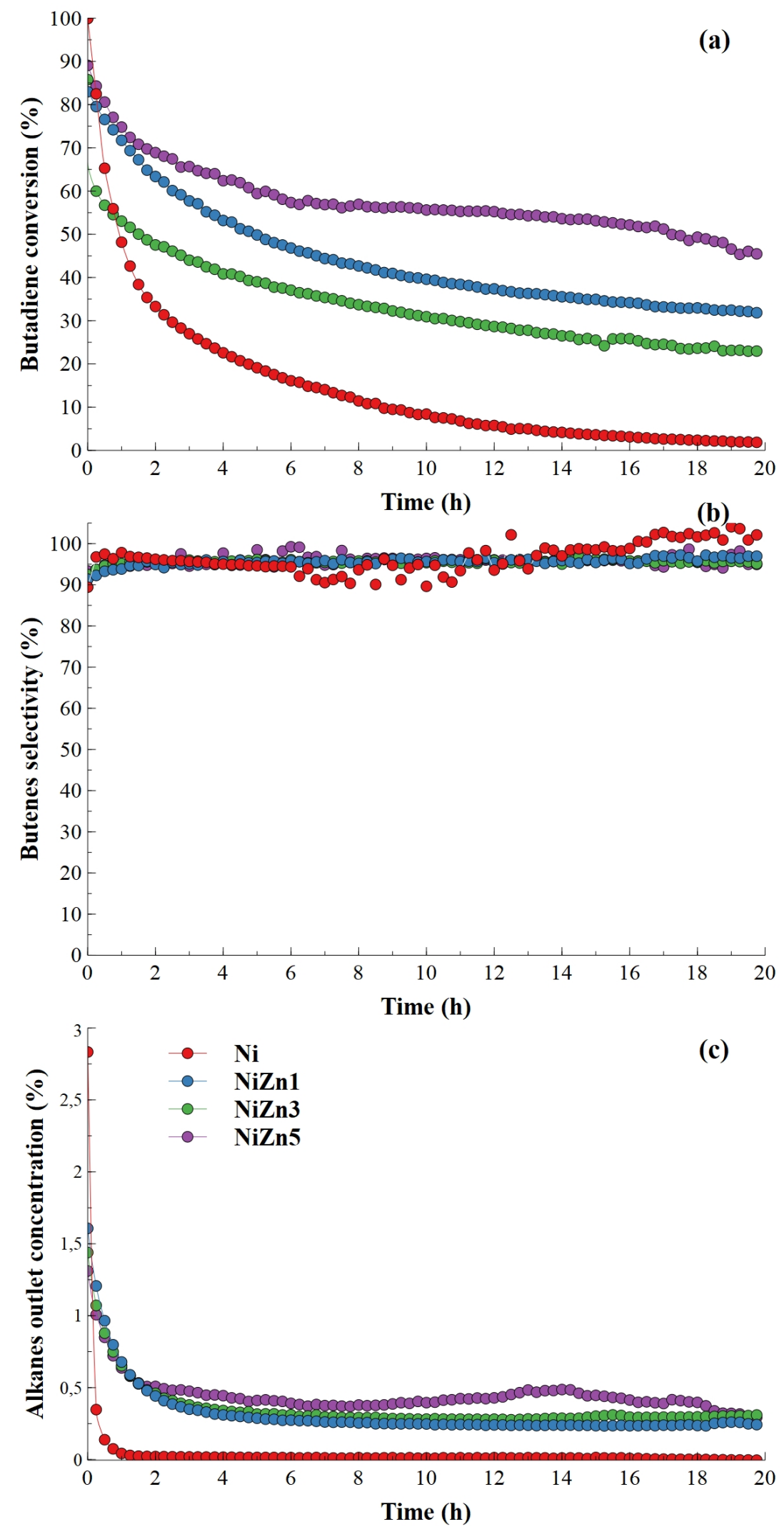

Figure 9. Evolution of the butadiene conversion (a), the selectivity to butenes (b) and the outlet alkanes concentration (c) with time on stream from an initial conversion of about $80-90 \%$ (at $20^{\circ} \mathrm{C}$ for Ni, $25{ }^{\circ} \mathrm{C}$ for NiZn1 and NiZn3, $35{ }^{\circ} \mathrm{C}$ for NiZn5) (0.5 wt $\% \mathrm{Ni}$ ) (10 mg of catalyst diluted with $\left.90 \mathrm{mg} \mathrm{TiO}_{2}\right)$ 
In contrast to what was observed during the temperature programmed reaction (Figure 8), the selectivity to butenes remains high (around 95\%) for all the catalysts (Figure 9b). The alkanes concentration is below $0.5-1 \%$ for all the catalysts and even extremely low for $\mathrm{Ni} / \mathrm{TiO}_{2}$ (Figure 9c), which is probably related to its very pronounced deactivation. The evolution of the selectivities in the various $\mathrm{C}_{4}$ products (1-butene, cis- and trans-2-butene, butane) with time on stream (Figure S4) reveals that 1-butene is the major product whatever the catalyst and that the proportion of the various butenes remains constant throughout the reaction. The butenes distribution is virtually identical regardless of the $\mathrm{Ni} / \mathrm{Zn}$ ratio (Figure $\mathrm{S} 4$ ). In the case of selective hydrogenation of polyunsaturated compounds, the formation of carbonaceous foulant is regarded as an important factor of deactivation, as previously discussed for the acetylene hydrogenation reaction, blocking the access to the active sites at the surface of the catalyst [65]. Note that contrary to the incomplete $\mathrm{C}_{2}$ carbon balance observed for the latter reaction and related to the oligomers formation, the $\mathrm{C}_{4}$ carbon balance for the butadiene hydrogenation is $97-99 \%$ for all the catalysts, indicating that only a marginal part of the $\mathrm{C}_{4}$ reactant or products could be responsible for the formation of carbonaceous deposit. Regarding the $\mathrm{C}_{3}$ compounds (propane and propene), the high propene content in the feed (30\%) makes the determination of the propene concentration inaccurate and prevents estimating the contribution of propene in the deactivation phenomenon. The temperature of decomposition and the amount of carbonaceous deposited on the catalysts surface after stability test were quantified by thermogravimetric analysis (TGA) performed under air flow (Figure S5). Considering the fact that the catalyst$\mathrm{TiO}_{2}$ mixtures used for the stability tests (Figure 9) contained very small amount of Ni (only $0.05 \mathrm{mg}$ of $\mathrm{Ni}$ in $100 \mathrm{mg}$ of catalyst $/ \mathrm{TiO}_{2}$ mixture), undiluted $\mathrm{Ni} / \mathrm{TiO}{ }_{2}$ and $\mathrm{Ni}-\mathrm{Zn} / \mathrm{TiO}_{2}$ samples were submitted to a stability test at $25^{\circ} \mathrm{C}$ for $20 \mathrm{~h}$ to better observe the variations of weight loss (Figure S5). A reference analysis was also performed on the bare $\mathrm{TiO}_{2}$ support, which was calcined then reduced at $450{ }^{\circ} \mathrm{C}$ for $2 \mathrm{~h}$, and exposed to the reactant gas mixture at $25{ }^{\circ} \mathrm{C}$ for 20 
h. In Figure S5, a decrease in the weight of the $\mathrm{TiO}_{2}$ support (1.2 $\mathrm{wt} \%$ ), can be observed in the temperature range between 150 and $600{ }^{\circ} \mathrm{C}$. It can be assigned to the removal of butadiene/propene adsorbed on the support as it is not active for the reaction. Regarding the Ni containing catalysts, the weight losses in the monometallic $\mathrm{Ni}$ and bimetallic Ni-Zn catalysts appear similar and rather close to the one of $\mathrm{TiO}_{2}$ (Figure S5).

Contrary to what was observed for the acetylene hydrogenation reaction, the addition of $\mathrm{Zn}$ to $\mathrm{Ni} / \mathrm{TiO}_{2}$ appears to have a beneficial effect on the stability of the catalysts in butadiene selective hydrogenation. Such a discrepancy might be related either to the difference in concentration of the polyunsaturated reactant in both reaction ( $2 \%$ for acetylene and $0.3 \%$ for butadiene) or to the strong tendency of acetylene to undergo coupling reactions, leading to the formation of a high proportion of oligomers (green oil), which is not the case of butadiene in our reaction conditions, as indicated by the $\mathrm{C}_{4}$ carbon balance. It is possible that the deactivation observed in the case of butadiene hydrogenation is due to the deposition of carbonaceous (coke) species resulting from the interaction of the surface with the various hydrocarbons (alkenes and alkanes) instead of oligomers, which may be favoured by the low reaction temperatures employed $\left(15-35^{\circ} \mathrm{C}\right)$. For Ni-based steam methane reforming (SMR) catalysts (such as $\mathrm{Ni} / \mathrm{MgAl}_{2} \mathrm{O}_{4}$ ), coke formation is considered to originate primarily from alkene formation [60]. A positive effect of $\mathrm{Zn}$ addition to $\mathrm{Ni}$ catalysts stability has been previously observed for ethanol steam reforming, and it also resulted in a decrease in the formation of carbonaceous deposit [66]. The enhanced stability was ascribed to the formation of $\mathrm{Ni}-\mathrm{Zn}$ alloy, resulting in the dilution of large surface ensembles of $\mathrm{Ni}$ metal atoms by $\mathrm{Zn}$ atoms and the according inhibition of carbon deposition [66]. A lower formation of carbonaceous compounds was also observed on a $\mathrm{Zn}$ modified $\mathrm{Ni} / \mathrm{Al}_{2} \mathrm{O}_{3}$ catalysts during selective hydrogenation of acetylene [67], however, the authors ascribed this phenomenon to a higher Ni phase dispersion in the zinc aluminate phase formed in ternary Ni-Zn-Al catalyst, and to a decrease in the number of surface 
acid sites compared to $\mathrm{Ni} / \mathrm{Al}_{2} \mathrm{O}_{3}$, rather than to the formation of an intermetallic NiZn phase. Although the EDS results (Figure 4) may be questionable due to the possible evaporation of $\mathrm{Zn}$ under the beam, they could indicate that a part of $\mathrm{Zn}$ is not alloyed with $\mathrm{Ni}$ and is present on the $\mathrm{TiO}_{2}$ surface. Acidic sites are known to promote the adsorption of hydrocarbons and to provoke not only isomerization but also transformation into coke or $\mathrm{C}_{2}-\mathrm{C}_{6}$ hydrocarbons from cracking and disproportionation reactions $[60,68]$. A lower formation of coke on $\mathrm{Pd} / \mathrm{Zn}$ modified $\alpha-\mathrm{Al}_{2} \mathrm{O}_{3}$ was deduced by TGA after acetylene hydrogenation by comparison with the unmodified sample and was assigned to a decrease in the acidity of the surface induced by the $\mathrm{Zn}$ addition [69]. However, as previously mentioned, the weight losses observed for all the catalysts by TGA are rather low and similar (Figure S5), which seems to indicate that the carbonaceous deposit during butadiene reaction is limited and could hardly explain the strong deactivation of the $\mathrm{Ni} / \mathrm{TiO}_{2}$ catalyst, all the more so when compared with what has been observed for the hydrogenation of acetylene. Another assumption would be to consider a deactivation caused by the progressive passivation of the Ni nanoparticles surface by traces of $\mathrm{O}_{2}$ or $\mathrm{H}_{2} \mathrm{O}$ present in the reactant feed. Despite the reducing character of the reaction mixture employed, with $20 \% \mathrm{H}_{2}$, the low reaction temperature used for butadiene hydrogenation $\left(20^{\circ} \mathrm{C}\right.$ for $\mathrm{Ni} / \mathrm{TiO}_{2}$ up to $35^{\circ} \mathrm{C}$ for $\mathrm{Ni}-\mathrm{Zn} / \mathrm{TiO}_{2}$ ) might not be sufficient to prevent such a surface oxidation. This phenomenon was observed for $\mathrm{Ni} / \mathrm{Al}_{2} \mathrm{O}_{3}$ catalyst in $\mathrm{CO}_{2}$ methanation, with technical $\mathrm{CO}_{2}$ containing $\mathrm{O}_{2}$ impurities and resulted also in a deactivation of the catalyst [70]. A gradual deactivation of the intermetallic compound $\mathrm{Al}_{13} \mathrm{Fe}_{4}$ was observed during butadiene hydrogenation in batch reactor and ascribed to surface oxidation by traces of O-containing gas impurities $\left(\mathrm{O}_{2}, \mathrm{H}_{2} \mathrm{O}\right)$ present in the reactor [71]. In order to explore this hypothesis, a deactivated $\mathrm{Ni} / \mathrm{TiO}_{2}$ catalyst during 5 -hour reaction at $20{ }^{\circ} \mathrm{C}$ was treated under $\mathrm{H}_{2}$ at moderate temperature $\left(200^{\circ} \mathrm{C}\right)$ for $1 \mathrm{~h}$ to estimate whether the deactivation is reversible (Figure S6). From the TGA analyses reported in Figures 7 and S5 and the literature data $[60,72]$, the removal of 
carbonaceous deposit is not expected to occur at such a low temperature. After the treatment under $\mathrm{H}_{2}$ at $200{ }^{\circ} \mathrm{C}$, the monometallic nickel catalyst resubmitted to the reaction at $20{ }^{\circ} \mathrm{C}$, started again from a high initial butadiene conversion (99\%) before gradually deactivating with time in a similar way as in the first run (Figure S6). A second $\mathrm{H}_{2}$ treatment led to the same recovery of the high initial conversion followed by a similar period of deactivation (Figure S6). As a comparison, the NiZn5 catalyst tested under the same conditions, which was much more stable, and showed only very moderate deactivation in the $5 \mathrm{~h}$ reaction time, also restored its high initial conversion after treatment under $\mathrm{H}_{2}$. It appears from this experiment that $\mathrm{Ni} / \mathrm{TiO}_{2}$ can be regenerated by a reduction treatment in mild conditions, which support the assumption of a deactivation by surface oxidation of the Ni nanoparticles. The formation of bimetallic Ni$\mathrm{Zn}$ particles in the $\mathrm{Ni}-\mathrm{Zn} / \mathrm{TiO}_{2}$ samples may prevent or at least slow down the oxidation of $\mathrm{Ni}$, as previously reported for Urushibara Nickel catalysts (analogous to Raney Nickel) in which the presence of metallic $\mathrm{Zn}$ protects the nickel from oxidation in mild oxidative conditions [73]. Similarly, Mg-Al mixed oxide supported Ni-Zn catalyst showed enhanced resistance against Ni re-oxidation in methane tri-reforming at $800{ }^{\circ} \mathrm{C}$ and the protective effect of $\mathrm{Zn}$ was ascribed to the strong oxophilic character of $\mathrm{Zn}$, which prevents the oxidation of $\mathrm{Ni}$ [74]. This stabilization of the active metallic Ni sites by the presence of $\mathrm{Zn}$ could thus account for the higher stability of the $\mathrm{Ni}-\mathrm{Zn} / \mathrm{TiO}_{2}$ catalysts in butadiene hydrogenation. In the case of acetylene hydrogenation, the higher temperature of reaction $\left(165-175^{\circ} \mathrm{C}\right)$ may limit this possible oxidation in reducing atmosphere, resulting in a more stable Ni catalyst. 


\section{CONCLUSION}

In this contribution, $\mathrm{TiO}_{2}$-supported bimetallic $\mathrm{Ni}-\mathrm{Zn}$ catalysts prepared by codeposition-precipitation with urea, with low Ni loadings ( $0.5 \mathrm{wt} \%)$, demonstrated relatively high selectivity to alkenes ( $85 \%$ to ethylene and $95 \%$ to butenes) with very limited alkanes formation in the reactions of selective hydrogenation of pure acetylene and of butadiene in the presence of an excess of propene, respectively. One of the main effects of the combination of $\mathrm{Ni}$ with $\mathrm{Zn}$ is to reduce the formation of oligomers in acetylene hydrogenation, underlining again that a low production of ethane is not the only parameter to identify a selective catalyst in this type of reaction.

Whilst the Ni-Zn samples could maintain a good level of conversion during around 20h time on stream (from $80-90 \%$ to around $60 \%$ ) for butadiene selective hydrogenation at low temperature $\left(\leq 35^{\circ} \mathrm{C}\right)$ whereas monometallic Ni deactivated rapidly, a reverse trend was observed for acetylene hydrogenation performed at higher temperature $\left(>165^{\circ} \mathrm{C}\right)$. It shows that, although these two reactions can be classified as analogous, the behavior of the catalysts strongly depends on the structure of the polyunsaturated hydrocarbon and/or the reaction conditions. Improving the stability of these catalysts is therefore an important step to consider their use as an alternative to standard commercial PdAg catalysts. The main limitation encountered in this study is the difficulty to control the composition of the bimetallic NiZn nanoparticles after reduction under $\mathrm{H}_{2}$ due to the proximity of the $\mathrm{Ni}^{2+}$ reduction and $\mathrm{Zn}$ sublimation temperatures. Among the paths envisaged to improve the performance of these NiZn catalysts, the development of synthesis methods allowing a finer control of their composition can be considered as a judicious approach. 


\section{ACKNOWLEDGMENT}

Dr. Zhao Wang thanks the China Scholarship Council (CSC) for his PhD scholarship. The authors thank the French METSA network for free access to JEOL ARM 200F microscope. Zhao Wang also thanks Prof. Haolin Tang, and Prof. Haining Zhang for their suggestions on writing manuscript. 


\section{REFERENCES}

1. B.J. Burger, M.E. Thompson, W.D. Cotter, J.E. Bercaw, J. Am. Chem. Soc. 112, 1566 (1990)

2. N.S. Schbib, M.A. García, C.E. Gígola, A.F. Errazu, Ind. Eng. Chem. Res. 35, 1496 (1996)

3. E.L. Mohundro, in American Institute of Chemical Engineers 15th Ethylene Producers Conference, New Orleans(2003)

4. M.L. Derrien, in Studies in Surface Science and Catalysis, ed. L. Cerveny (Elsevier, 1986), pp. 613-666

5. F.H. Puls, K.D. Ruhnke, (United States Exxon Research \& Engineering Co. (Florham Park, NJ) $4260840 \quad$ 1981)

6. J. Howeizi, S. Taghvaei-Ganjali, M. Malekzadeh, F. Motiee, S. Sahebdelfar, Res. Chem. Intermed. 45, 3165 (2019)

7. R.J. Gartside, T. Skourlis, (Lummus Technology Inc. (1515 Broad Street, Bloomfield NJ 07003-3096, US) EP1773739, 2007)

8. S.A. Blankenship, R.W. Voight, J.A. Perkins, J.E. Fried Jr, (Google Patents, 2003)

9. Q. Zhang, J. Li, X. Liu, Q. Zhu, Appl. Catal., A 197, 221 (2000)

10. W. Ludwig, A. Savara, R.J. Madix, S. Schauermann, H.-J. Freund, J. Phys. Chem. C 116, 3539 (2012)

11. W. Ludwig, A. Savara, K.-H. Dostert, S. Schauermann, J. Catal. 284, 148 (2011)

12. M. Wilde, K. Fukutani, W. Ludwig, B. Brandt, J.H. Fischer, S. Schauermann, H.J. Freund, Angew. Chem. Int. Ed. 47, 9289 (2008)

13. B. Ngamsom, N. Bogdanchikova, M.A. Borja, P. Praserthdam, Catal. Commun. 5, 243 (2004)

14. A. Pachulski, R. Schödel, P. Claus, Appl. Catal., A 400, 14 (2011)

15. S. Komeili, M.T. Ravanchi, A. Taeb, Res. Chem. Intermed. 44, 1335 (2018)

16. M.T. Ravanchi, S. Fadaeerayeni, M.R. Fard, Res. Chem. Intermed. 42, 4797 (2016)

17. D. Teschner, J. Borsodi, A. Wootsch, Z. Révay, M. Hävecker, A. Knop-Gericke, S.D. Jackson, R. Schlögl, Science 320, 86 (2008)

18. N.A. Khan, S. Shaikhutdinov, H.-J. Freund, Catal. Lett. 108, 159 (2006)

19. G. Vilé, D. Albani, N. Almora-Barrios, N. López, J. Pérez-Ramírez, ChemCatChem 8, 21 (2016)

20. C. Louis, L. Delannoy, in Advances in Catalysis, Vol 64, ed. C. Song (2019), pp. 1-88

21. L.L. Zhang, M.X. Zhou, A.Q. Wang, T. Zhang, Chem. Rev. 120, 683 (2020)

22. R. Hou, W. Yu, M.D. Porosoff, J.G. Chen, T. Wang, J. Catal. 316, 1 (2014)

23. S. Leviness, V. Nair, A.H. Weiss, Z. Schay, L. Guczi, J. Mol. Catal. 25, 131 (1984)

24. P.T. Witte, P.H. Berben, S. Boland, E.H. Boymans, D. Vogt, J.W. Geus, J.G. Donkervoort, Top. Catal. 55, 505 (2012)

25. F. Studt, F. Abild-Pedersen, T. Bligaard, R.Z. Sørensen, C.H. Christensen, J.K. Nørskov, Science 320, 1320 (2008)

26. Z. Wang, G. Wang, C. Louis, L. Delannoy, J. Catal. 347, 185 (2017)

27. C.S. Spanjers, J.T. Held, M.J. Jones, D.D. Stanley, R.S. Sim, M.J. Janik, R.M. Rioux, J. Catal. 316, 164 (2014)

28. C.S. Spanjers, R.S. Sim, N.P. Sturgis, B. Kabius, R.M. Rioux, ACS Catal. 5, 3304 (2015)

29. M. Kang, M.W. Song, T.W. Kim, K.L. Kim, Can. J. Chem. Eng. 80, 63 (2002)

30. B. Bridier, N. López, J. Pérez-Ramírez, Dalton Trans. 39, 8412 (2010)

31. H. Li, H. Li, W.-L. Dai, W. Wang, Z. Fang, J.-F. Deng, Appl. Surf. Sci. $\quad$ 152, 25 (1999)

32. S.P. Lee, Y.W. Chen, J. Chem. Technol. Biotechnol. 75, 1073 (2000) 
33. S. Yoshida, H. Yamashita, T. Funabiki, T. Yonezawa, J. Chem. Soc., Faraday Trans. 1 F 80, 1435 (1984)

34. Y. Liu, X. Liu, Q. Feng, D. He, L. Zhang, C. Lian, R. Shen, G. Zhao, Y. Ji, D. Wang, Adv. Mater. 28, 4747 (2016)

35. Y. Chen, J. Chen, Appl. Surf. Sci. 387, 16 (2016)

36. K. Bourikas, C. Kordulis, A. Lycourghiotis, Chem. Rev. 114, 9754 (2014)

37. P. Burattin, M. Che, C. Louis, J. Phys. Chem. B 102, 2722 (1998)

38. A. Aguilar-Tapia, L. Delannoy, C. Louis, C.W. Han, V. Ortalan, R. Zanella, J. Catal. 344, 515 (2016)

39. G. Yuan, C. Louis, L. Delannoy, M.A. Keane, J. Catal. 247, 256 (2007)

40. D.M. Fernandes, R. Silva, A.A.W. Hechenleitner, E. Radovanovic, M.A.C. Melo, E.A.G. Pineda, Mater. Chem. Phys. 115, 110 (2009)

41. C. Ricolleau, J. Nelayah, T. Oikawa, Y. Kohno, N. Braidy, G. Wang, F. Hue, L. Florea, V. Pierron Bohnes, D. Alloyeau, Microscopy 62, 283 (2013)

42. A. Hugon, L. Delannoy, J.-M. Krafft, C. Louis, J. Phys. Chem. C 114, 10823 (2010)

43. T. Imoto, Y. Harano, Y. Nishi, S. Masuda, Bull. Chem. Soc. Jpn. 37, 441 (1964)

44. S. Lew, A.F. Sarofim, M. Flytzani-Stephanopoulos, Chem. Eng. Sci. $\quad 47, \quad 1421$ (1992)

45. M. Liang, W. Kang, K. Xie, J. Nat. Gas Chem. 18, 110 (2009)

46. M.A. Valenzuela, P. Bosch, J. Jiménez-Becerrill, O. Quiroz, A.I. Páez, J. Photochem. Photobiol., A 148, 177 (2002)

47. K. Hadjiivanov, M. Mihaylov, N. Abadjieva, D. Klissurski, J. Chem. Soc., Faraday Trans. 94, 3711 (1998)

48. J. van de Loosdrecht, A.M. van der Kraan, A.J. van Dillen, J.W. Geus, J. Catal. 170, 217 (1997)

49. D. Kohl, M. Henzler, G. Heiland, Surf. Sci. 41, 403 (1974)

50. D.F. Anthrop, A.W. Searcy, J. Phys. Chem. 68, 2335 (1964)

51. W. Pearson, W. Pearson, An Alphabetical Index of Work on Metals and Alloys, 1958)

52. I.S. Mashkovsky, G.N. Baeva, A.Y. Stakheev, M.N. Vargaftik, N.Y. Kozitsyna, Moiseev, II, Mendeleev Commun. 24, 355 (2014)

53. D.L. Trimm, N.W. Cant, I.O. Liu, Catal. Today 178, 181 (2011)

54. B. Hammer, J.K. Nørskov, Adv. Catal. 45, 71 (2000)

55. G. Bond, Discuss. Faraday Soc. 41, 200 (1966)

56. A.H. Al-ShaikhAli, A. Jedidi, L. Cavallo, K. Takanabe, Chem. Commun. 51, 12931 (2015)

57. A.H. Al-ShaikhAli, A. Jedidi, D.H. Anjum, L. Cavallo, K. Takanabe, ACS Catal. 7, 1592 (2017)

58. R.T. Vang, K. Honkala, S. Dahl, E.K. Vestergaard, J. Schnadt, E. Lægsgaard, B.S. Clausen, J.K. Nørskov, F. Besenbacher, Nat. Mater. 4, 160 (2005)

59. W.-J. Kim, S.H. Moon, Catal. Today 185, 2 (2012)

60. M.D. Argyle, C.H. Bartholomew, Catalysts 5, 145 (2015)

61. M.T. Ravanchi, S. Sahebdelfar, S. Komeili, Rev. Chem. Eng. 34, 215 (2018)

62. I.Y. Ahn, J.H. Lee, S.K. Kim, S.H. Moon, Appl. Catal., A 360, 38 (2009)

63. A. Sárkány, L. Guczi, A.H. Weiss, Appl. Catal. 10, 369 (1984)

64. Á. Molnár, A. Sárkány, M. Varga, J. Mol. Catal. A: Chem. 173, 185 (2001)

65. M. Stammbach, D. Thomas, D. Trimm, M. Wainwright, Appl. Catal. 58, 209 (1990)

66. C. Anjaneyulu, L.O. da Costa, M.C. Ribeiro, R.C. Rabelo-Neto, L.V. Mattos, A. Venugopal, F.B. Noronha, Appl. Catal., A 519, 85 (2016)

67. J. Rodriguez, A. Marchi, A. Borgna, A. Monzón, J. Catal. 171, 268 (1997)

68. P. Berteau, S. Ceckiewicz, B. Delmon, Appl. Catal. 31, 361 (1987) 
69. S. Chinayon, O. Mekasuwandumrong, P. Praserthdam, J. Panpranot, Catal. Comm. 9, 2297 (2008)

70. B. Mutz, A.M. Ganzler, M. Nachtegaal, O. Muller, R. Frahm, W. Kleist, J.D. Grunwaldt, Catalysts 7, 279 (2017)

71. L. Piccolo, L. Kibis, J. Catal. 332, 112 (2015)

72. J.L. Figueiredo, (Springer Netherlands, Dordrecht, 1982), pp. 45-63

73. I. Jacob, M. Fisher, Z. Hadari, M. Herskowitz, J. Wlsniak, N. Shamir, M.H. Mintz, J. Catal. 101, 28 (1986)

74. R. Kumar, K.K. Pant, Appl. Surf. Sci. 515, 146010 (2020)

\section{First memories of Michel Che}

Michel Che was already the head of the LRS lab, when in 1979, I (Catherine Louis) chose to do my $\mathrm{PhD}$ under his direction. He had been appointed as a full Professor, a few years before, (coming from the Institut de Catalyse in Lyon where his main research focused on the characterization of oxide defects and oxide doping by EPR). His first research fields at LRS concerned the study of the physico-chemical phenomena occurring during the preparation of supported catalysts in order to better control the dispersion of the supported phase. When I arrived, the lab did not have many characterisation techniques. I remember an old EPR spectrometer in one room and in the preparation room, of two glass vacuum lines with mercury pumps and grease stopcocks, in which the catalysts were pretreated under different gas before EPR characterisation. There were also UV-Visible and IR spectrometers. During the 5 years of my PhD, I directly worked under his supervision to develop a method of preparation allowing to disperse Mo ions as better as possible on a silica support. The EPR spectroscopy was my main technique to characterize the Mo dispersion (in fact $\mathrm{Mo}^{5+}$ ) and to study various reactions of electron transfer at the surface of $\mathrm{Mo} / \mathrm{SiO}_{2}$.

I remember the one-on-one scientific meetings with him and his long monologues from which I had afterwards to extract the follow-up to be given to my work, which was a way to let me free to direct my research on my own.

Under his direction, the LRS laboratory has gradually grown, equipping itself with numerous state-of-the-art characterization devices, recruiting many researchers and lecturers over the years, and gradually gaining national and international recognition.

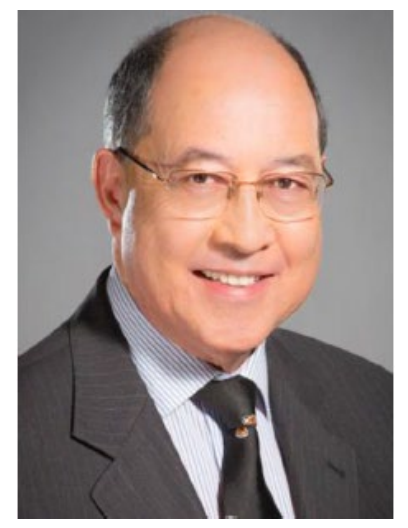




\title{
Supplementary Information
}

\section{Bimetallic $\mathrm{Ni}-\mathrm{Zn} / \mathrm{TiO}_{2}$ catalysts for selective hydrogenation of alkyne and alkadiene impurities from alkenes stream}

\author{
Zhao Wang ${ }^{1,3}$, Guillaume Wang ${ }^{2}$, Catherine Louis ${ }^{1}$, Laurent Delannoy ${ }^{1 *}$
}

1- Sorbonne Université, CNRS, Laboratoire de Réactivité de Surface, LRS, F-75252 Paris, France.

2- Université Paris Diderot, Sorbonne Paris Cité, CNRS, Laboratoire Matériaux et Phénomènes Quantiques, UMR 7162, 75013, Paris, France.

3-Present address: State Key Laboratory Advance Technology for Materials Synthesis and Processing, School of Materials Science and Engineering, Wuhan University of Technology, 122, Luoshi Road, Wuhan, 430070, China. 


\section{Catalytic performances evaluation}

Gases. The gases used for the catalyst preparation and testing were purchased from Air Liquide France: Propylene 3.5 (99.5\% purity), 1,3-butadiene (6000 ppm mixture in $\mathrm{He}), \mathrm{H}_{2}(99.999 \%$ purity), Helium (99.999\% purity), Synthetic Air (99.99\% purity) and $\mathrm{N}_{2}$ (99.999\% purity).

\section{Conversion and selectivities}

1) Hydrogenation of Acetylene :

$$
\begin{gathered}
\text { Conversion }_{\text {Acetylene }}=\frac{\text { Acetylene }_{\text {in }}-\text { Acetylene }_{\text {out }}}{\text { Acetylene }_{\text {in }}} \\
\text { Selectivity }_{\text {Ethylene }}=\frac{\text { Ethylene }_{\text {out }}}{\text { Acetylene }_{\text {in }}-\text { Acetylene }_{\text {out }}} \\
\text { Selectivity }_{\text {Ethane }}=\frac{\text { Ethane }_{\text {out }}}{\text { Acetylene }_{\text {in }}-\text { Acetylene }_{\text {out }}} \\
\text { Selectivity }_{\text {oligomers }}=1-\left(\text { Selectivity }_{\text {Ethylene }}+\text { Selectivity }_{\text {Ethane }}\right)
\end{gathered}
$$

2) Selective hydrogenation of butadiene in excess of propene :

$$
\begin{gathered}
\text { Conversion }_{\text {Butadiene }}=\frac{\text { Butadiene }_{\text {in }}-\text { Butadiene }_{\text {out }}}{\text { Butadiene }_{\text {in }}} \\
\text { Selectivity }_{\text {butenes }}=\frac{\sum \text { Butenes }_{\text {out }}}{\text { Butadiene }_{\text {in }}-\text { Butadiene }_{\text {out }}} \\
\text { with } \sum \text { Butenes }_{\text {out }}=1 \text { _butene }_{\text {out }}+\text { cis_2_butene }_{\text {out }}+\text { trans_2_butene }_{\text {out }} \\
\text { Alkanes concentration }=\frac{\text { Propane }_{\text {out }}+\text { Butane }_{\text {out }}}{\text { Propane }_{\text {out }}+\text { Butane }_{\text {out }}+\sum \text { Butenes }_{\text {out }}+\text { Butadiene }_{\text {out }}+\text { Propene }_{\text {in }}}
\end{gathered}
$$




\section{Activity and turnover frequency (TOF)}

The catalytic activity is expressed considering that $\mathrm{Ni}$ is the only active metal for the reaction and as follows:

$$
\text { Activity }\left(\mathrm{mol} \cdot \mathrm{s}^{-1} \cdot \mathrm{g}_{\mathrm{Ni}}^{-1}\right)=\frac{\text { Reactant conversion } \times \mathrm{Q}_{\text {reactant }}}{\mathrm{m}_{\text {catalyst }} \times \mathrm{wt} \% \mathrm{Ni}}
$$

Reactant conversion is the conversion of acetylene or butadiene; $\mathrm{Q}$ reactant is the molar flow rate $\left(\mathrm{mol} . \mathrm{s}^{-1}\right)$ of the reactant (acetylene or butadiene) at room temperature, $\mathrm{m}_{\text {catalyst }}$ is the catalyst mass used for the test, $\mathrm{wt} \% \mathrm{Ni}$ is the Ni loading of the catalyst determined by XRF;

$$
\operatorname{TOF}\left(\mathrm{s}^{-1}\right)=\frac{\text { Activity } \cdot \mathrm{M}_{\mathrm{Ni}}}{\text { Dispersion }}
$$

Dispersion is the metal dispersion, which was calculated from equation (3) using the formula described by Scholten [1]:

$$
D=10^{21} \times \frac{6 \times M \times \rho_{\text {site }}}{d \times \rho_{\text {metal }} \times N}
$$

for which $\mathrm{M}$ is the metal atomic weight $\left(\mathrm{g} \mathrm{mol}^{-1}\right) ; \rho_{\text {site }}$ is the metal surface site density; $\mathrm{d}$ is the average particle size; $\rho_{\text {metal }}$ is the metal density $\left(8.908 \mathrm{~g} \mathrm{~cm}^{-3}\right.$ for nickel); $\mathrm{N}$ is the Avogadro constant $\left(6.02 \times 10^{23} \mathrm{~mol}^{-1}\right)$. For monometallic nickel, $\rho_{\text {site } \mathrm{Ni}}$ is equal to 15.4 atoms $\mathrm{nm}^{-2}$ according to [1]. For the NiZn catalysts, the surface metal density ( $\rho_{\text {site NiZn }}$ ) was estimated using the average $\mathrm{Ni} / \mathrm{Zn}$ atomic ratios deduced from the XRF measurements obtained for each Ni$\mathrm{Zn} / \mathrm{TiO}_{2}$ samples after reduction by the relation

$$
\rho_{\text {site NiZn }}=\rho_{\text {site } \mathrm{Ni}} \times \frac{\frac{\mathrm{Ni}}{\mathrm{Zn}}}{1+\frac{\mathrm{Ni}}{\mathrm{Zn}}}
$$

In this calculation, it is also assumed that the surface composition of the particles is the same as the bulk composition.

\section{Reference}

1. J. Scholten, A. Pijpers, A. Hustings, Catal. Rev. 27, 151 (1985) 
Figure S1: XRD of calcined then reduced DPU NiZn 1:5/ $\mathrm{TiO}_{2}$ sample.

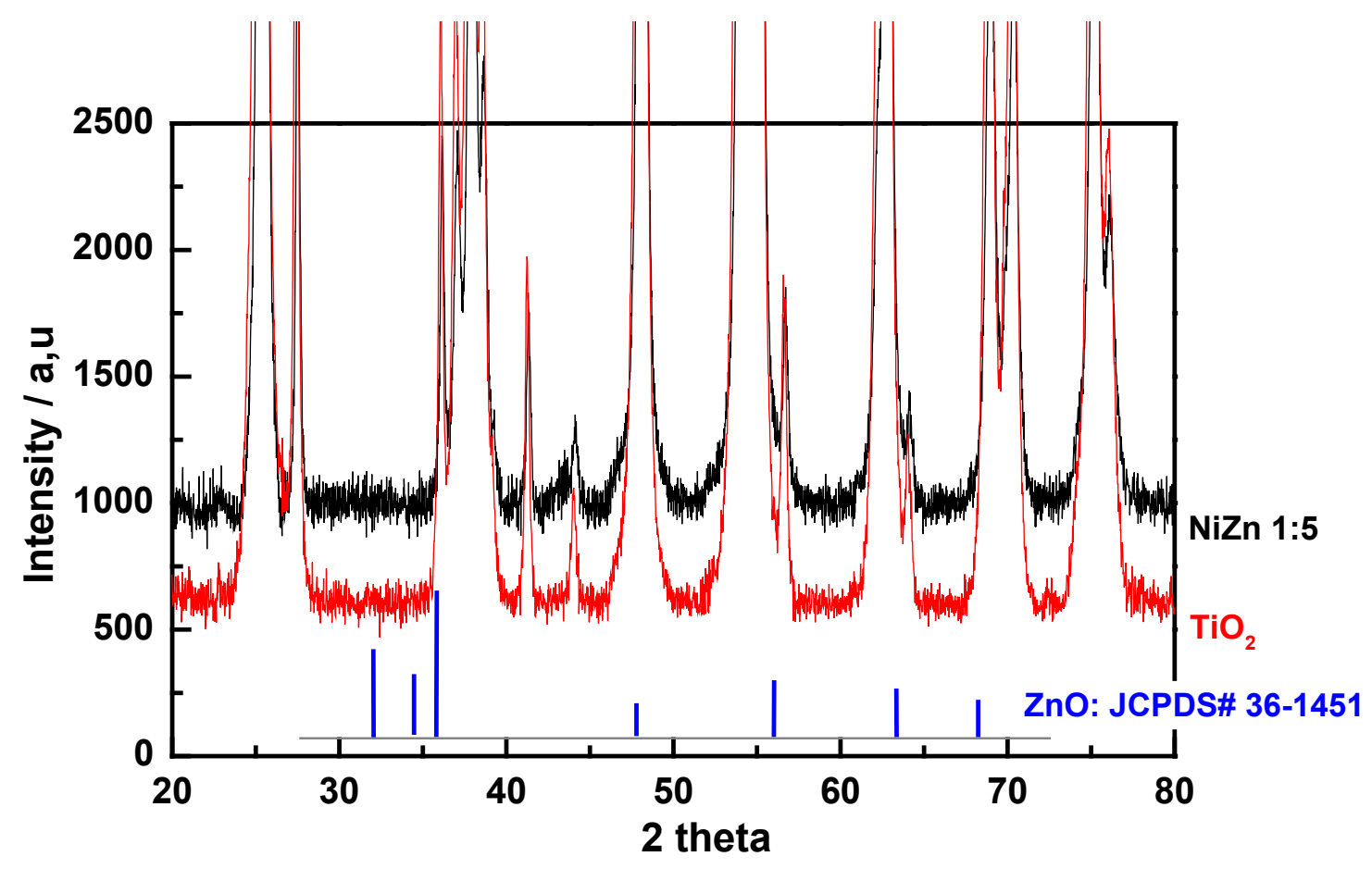


Table S1: Percentage of reduced $\mathrm{Ni}^{2+}$ calculated from the TPR

\begin{tabular}{|c|c|c|c|c|c|c|c|}
\hline & Sample & $\begin{array}{l}\text { Sample weight } \\
\text { for TPR / mg }\end{array}$ & $\begin{array}{c}\text { NiO weight / } \\
\text { mg }\end{array}$ & $\begin{array}{l}\text { Integrated area } \\
\text { from TPR data }\end{array}$ & $\mid \begin{array}{c}\text { Maximum of } \\
\text { reduction } \\
\text { peak in TPR } \\
/^{\circ} \mathrm{C}\end{array}$ & $\begin{array}{c}\text { Reduced NiO } \\
\text { calculated } \\
\text { from TPR / } \\
\text { mg }\end{array}$ & $\begin{array}{l}\text { Percentage } \\
\text { of reduced } \\
\mathrm{Ni}^{2+}(\%)\end{array}$ \\
\hline Reference & $\mathrm{NiO}$ & 112.5 & 112.5 & 647 & 430 & 112.5 & 100 \\
\hline \multirow{4}{*}{ Catalysts } & $\mathbf{N i}$ & 113.5 & 0.780 & 3.72 & 400 & 0.65 & 83 \\
\hline & NiZn1 & 114.5 & 0.720 & 3.91 & 410 & 0.68 & 94 \\
\hline & NiZn3 & 110.6 & 0.700 & 4.48 & 430 & 0.78 & 111 \\
\hline & NiZn5 & 101.1 & 0.710 & 3.94 & 440 & 0.69 & 97 \\
\hline
\end{tabular}


Figure S2: Evolution of the selectivity to oligomers with acetylene conversion during temperature programmed reaction of acetylene hydrogenation for the calcined then reduced $\mathrm{Ni}$ and $\mathrm{Ni}-\mathrm{Zn} / \mathrm{TiO}_{2}$ catalysts $(0.5 \mathrm{wt} \% \mathrm{Ni})(50 \mathrm{mg}$ of catalyst diluted with $150 \mathrm{mg} \mathrm{SiC})$.

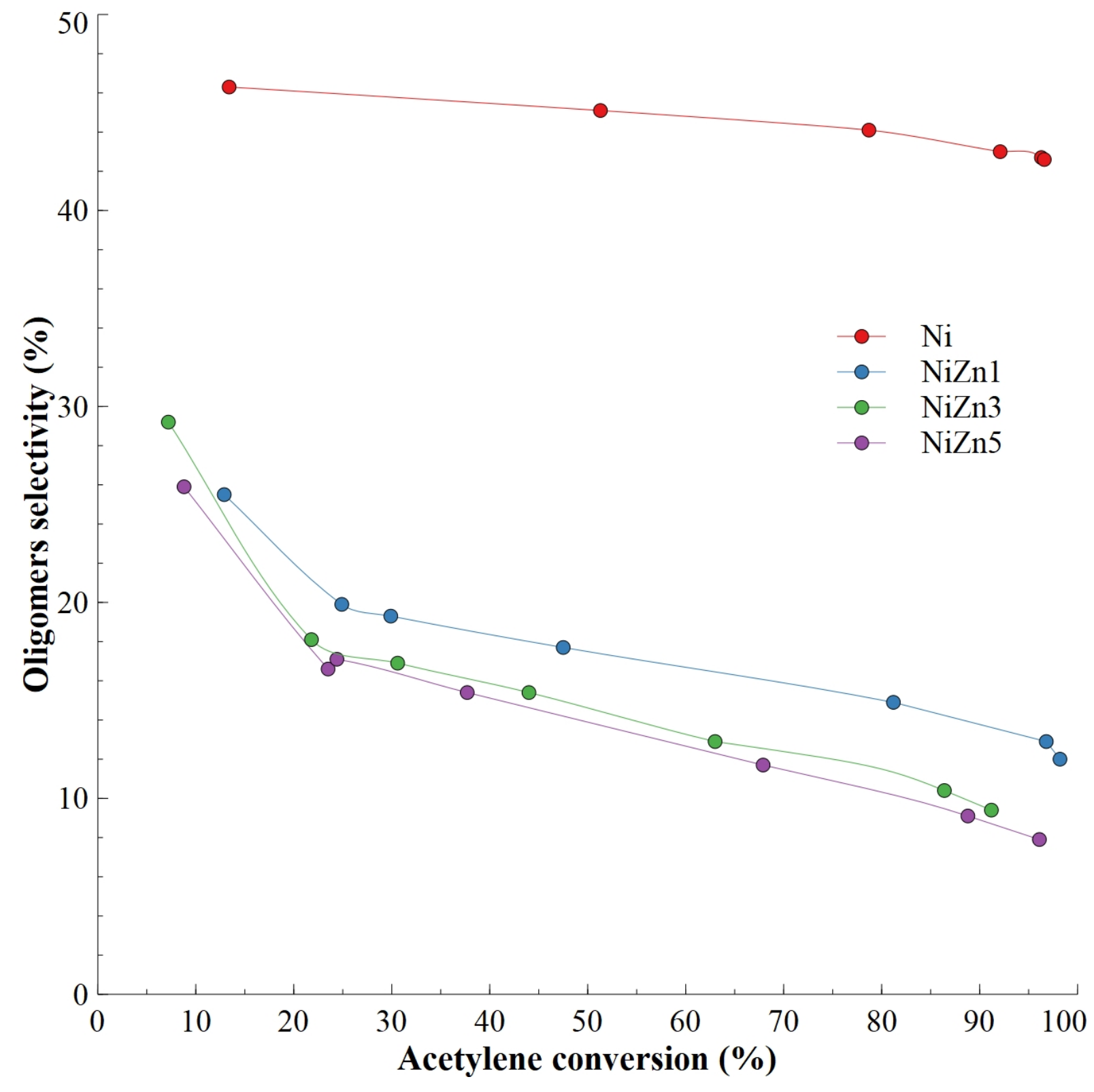


Figure S3: Evolution of the selectivity to ethane (a) and oligomers (b) with time on stream during acetylene hydrogenation for the calcined then reduced $\mathrm{Ni}$ and $\mathrm{Ni}-\mathrm{Zn} / \mathrm{TiO}_{2}$ catalysts $(0.5$ $\mathrm{wt} \% \mathrm{Ni}$ ) (50 mg of catalyst diluted with $150 \mathrm{mg} \mathrm{SiC})$.
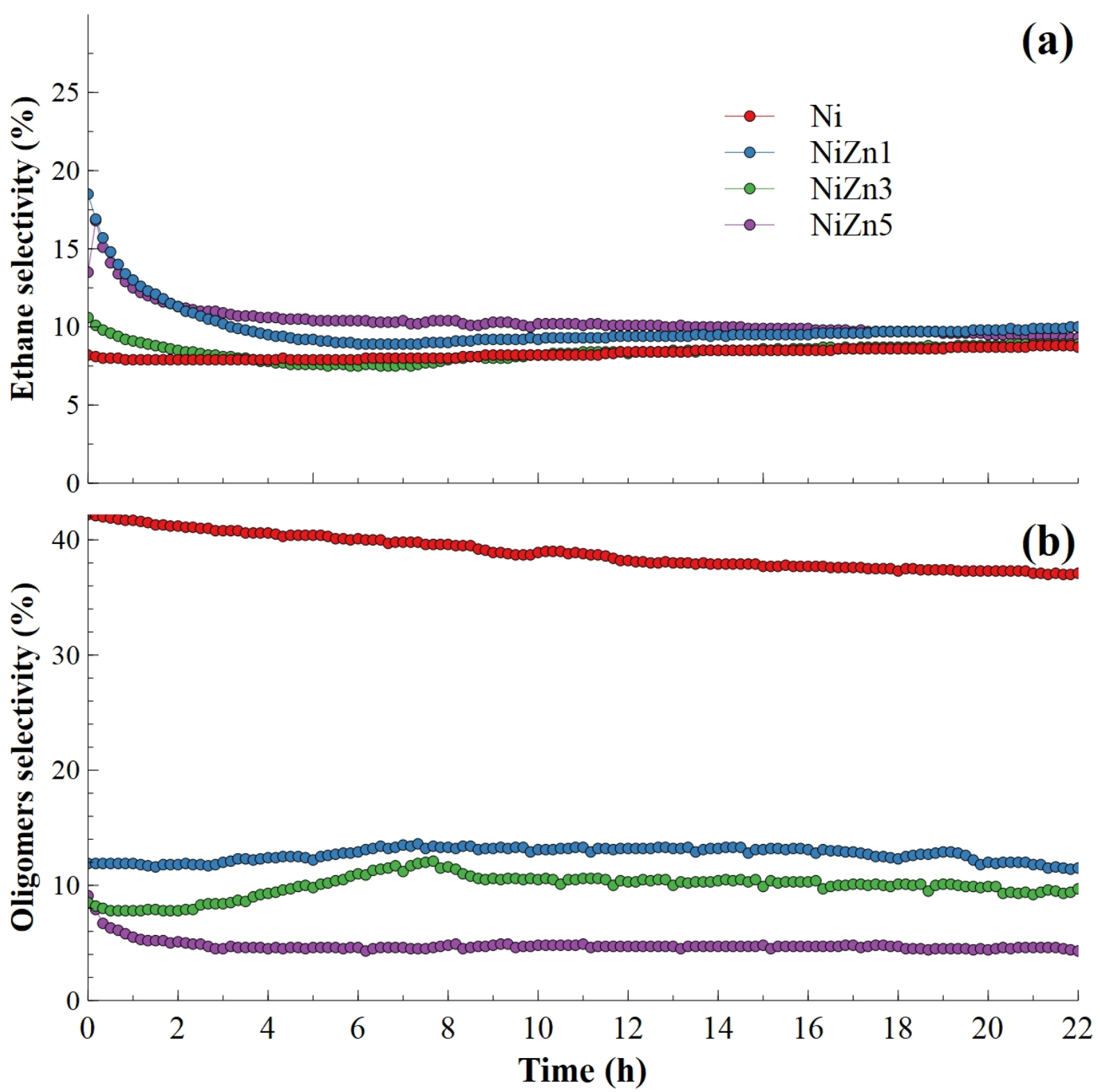
Figure S4: Evolution of the selectivity to 1-butene, trans-2-butene, cis-2-butene and butane with time on stream during butadiene hydrogenation for the calcined then reduced $\mathrm{Ni}$ and $\mathrm{Ni}$ $\mathrm{Zn} / \mathrm{TiO}_{2}$ catalysts $(0.5 \mathrm{wt} \% \mathrm{Ni})(10 \mathrm{mg}$ of catalyst diluted with $90 \mathrm{mg} \mathrm{TiO} 2)$.
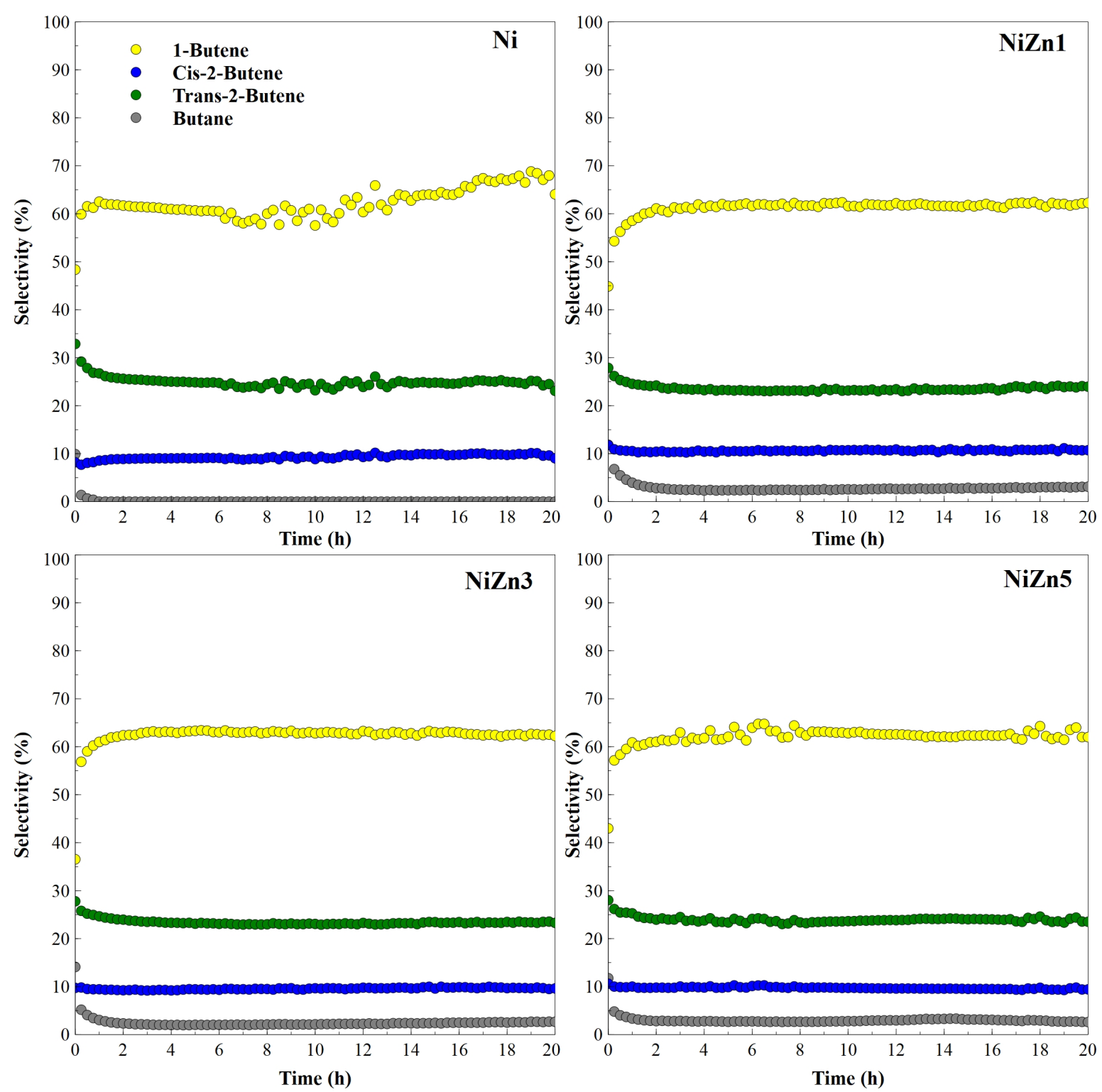
Figure S5: Thermogravimetric analyses performed in air of $\mathrm{TiO}_{2}$ support and undiluted Ni$\mathrm{Zn} / \mathrm{TiO}_{2}$ samples after $20 \mathrm{~h}$ of butadiene hydrogenation test at $25^{\circ} \mathrm{C}$. $\mathrm{TiO}_{2}$ was previously calcined then reduced at $450{ }^{\circ} \mathrm{C}$ and exposed to reactant gas mixture for $20 \mathrm{~h}$ at $25{ }^{\circ} \mathrm{C}$.

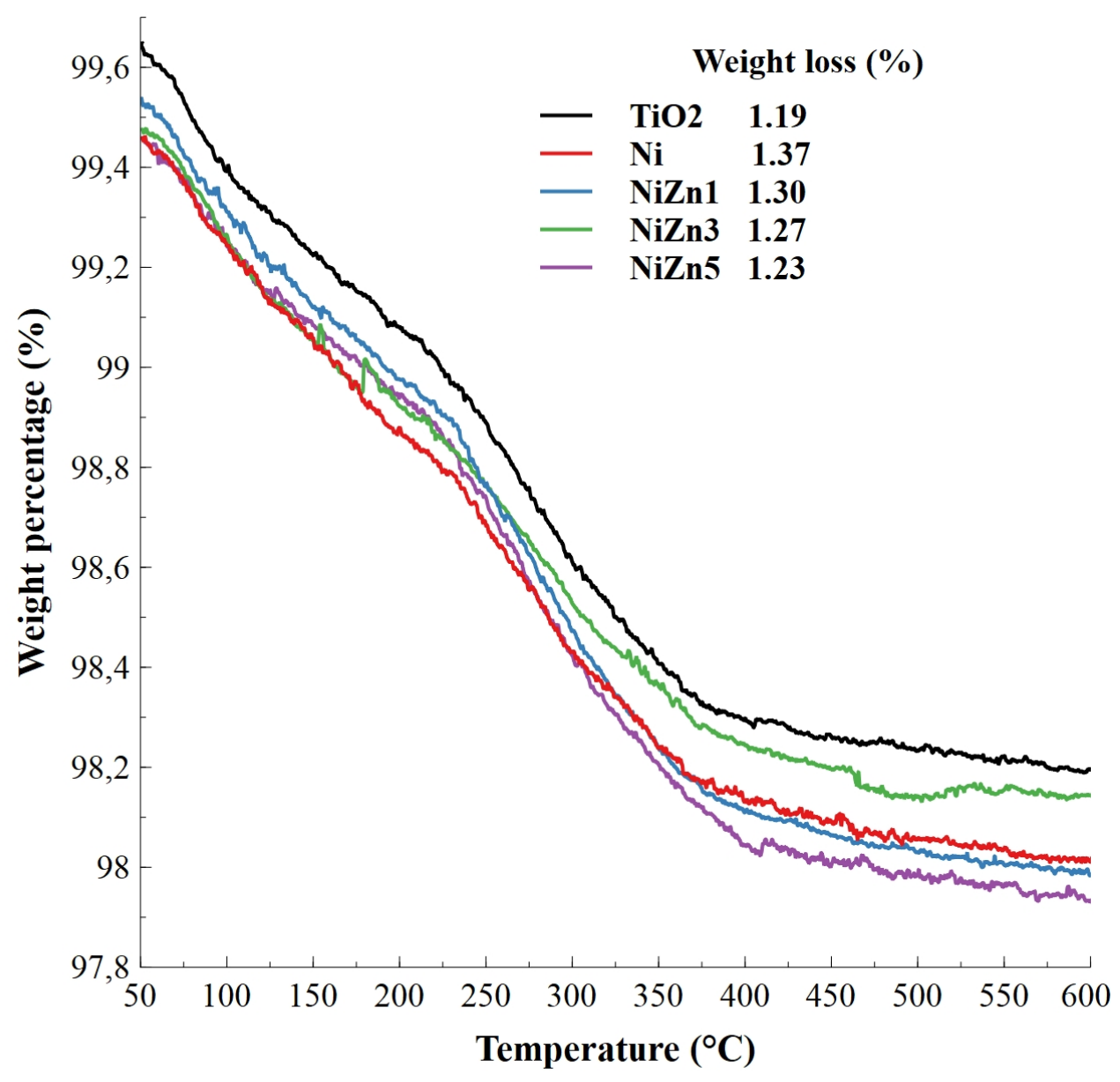


Figure S6: Evolution of the butadiene conversion with time on stream at $20{ }^{\circ} \mathrm{C}$ for $\mathrm{Ni}$ and NiZn5 catalysts after thermal treatment under $\mathrm{H}_{2}$ at $200{ }^{\circ} \mathrm{C}$ for $1 \mathrm{~h}\left(20\right.$ to $200{ }^{\circ} \mathrm{C}$ at $\left.3{ }^{\circ} \mathrm{C} \cdot \mathrm{min}^{-1}\right)$ $(0.5 \mathrm{wt} \% \mathrm{Ni})\left(10 \mathrm{mg}\right.$ of $\mathrm{Ni} / \mathrm{TiO}_{2}$ and $15 \mathrm{mg}$ of $\mathrm{NiZn}(1: 5) / \mathrm{TiO}_{2}$ diluted with $\left.90 \mathrm{mg} \mathrm{TiO}_{2}\right)$. The hatched areas correspond to the periods of treatment under $\mathrm{H}_{2}$ at $200^{\circ} \mathrm{C}$.

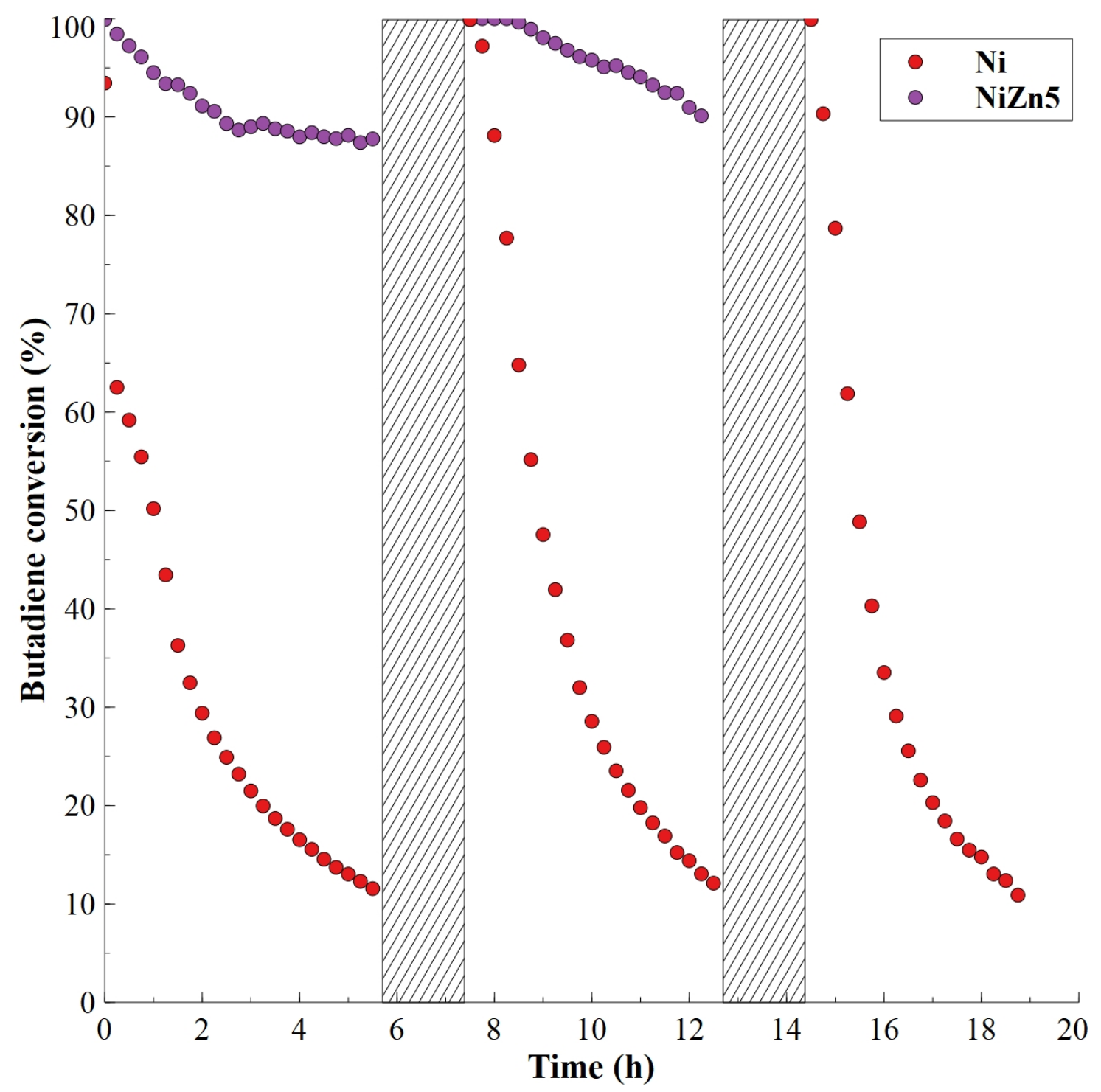

